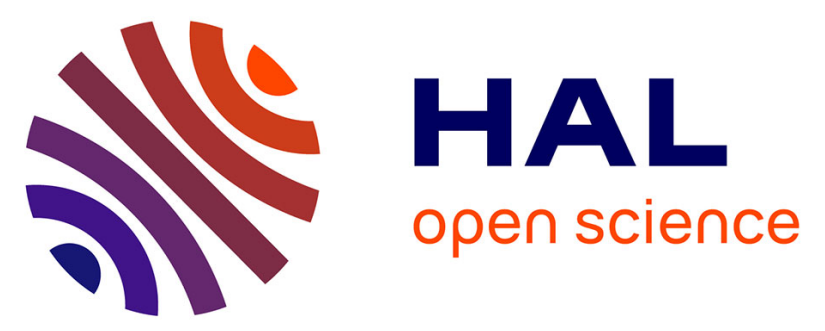

\title{
Zooplankton community response to the winter 2013 deep convection process in the NWMediterranean Sea
}

\author{
Katty Donoso, Francois Carlotti, Marc Pagano, Brian P. V. Hunt, Rubén
}

Escribano, L. Berline

\section{- To cite this version:}

Katty Donoso, Francois Carlotti, Marc Pagano, Brian P. V. Hunt, Rubén Escribano, et al.. Zooplankton community response to the winter 2013 deep convection process in the NWMediterranean Sea. Journal of Geophysical Research. Oceans, 2017, 122 (3), pp.2319-2338. 10.1002/2016jc012176 . hal-01622031

\section{HAL Id: hal-01622031 \\ https://hal-amu.archives-ouvertes.fr/hal-01622031}

Submitted on 20 Dec 2017

HAL is a multi-disciplinary open access archive for the deposit and dissemination of scientific research documents, whether they are published or not. The documents may come from teaching and research institutions in France or abroad, or from public or private research centers.
L'archive ouverte pluridisciplinaire HAL, est destinée au dépôt et à la diffusion de documents scientifiques de niveau recherche, publiés ou non, émanant des établissements d'enseignement et de recherche français ou étrangers, des laboratoires publics ou privés. 


\section{Journal of Geophysical Research: Oceans}

\section{RESEARCH ARTICLE \\ 10.1002/2016JC012176 \\ Zooplankton community response to the winter 2013 deep convection process in the NW Mediterranean Sea}

\section{Special Section: \\ Dense Water Formations in the North Western Mediterra- nean: From the Physical Forc- ings to the Biogeochemical Consequences}

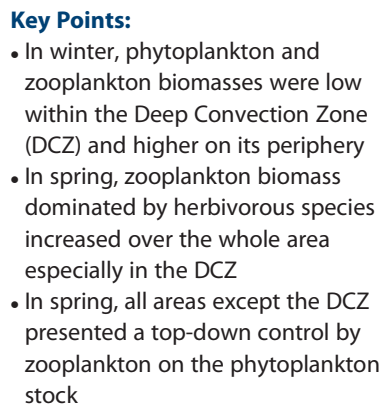

Supporting Information: - Supporting Information S1

Correspondence to:

F. Carlotti,

francois.carlotti@mio.osupytheas.fr

Citation:

Donoso, K., F. Carlotti, M. Pagano,

B. P. V. Hunt, R. Escribano, and

L. Berline (2017), Zooplankton

community response to the winter 2013 deep convection process in the NW Mediterranean Sea, J. Geophys. Res. Oceans, 122, 2319-2338, doi:10.1002/ 2016JC012176.

Received 27 JUL 2016 Accepted 4 JAN 2017 Accepted article online 8 FEB 2017 Published online 23 MAR 2017

(C) 2017. American Geophysical Union. All Rights Reserved.

\author{
Katty Donoso ${ }^{1}$ (D), François Carlotti ${ }^{1}$, Marc Pagano ${ }^{1}$, Brian P. V. Hunt 1,2,3,

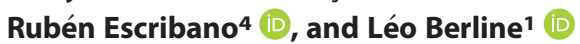 \\ ${ }^{1}$ Aix-Marseille Univ, Univ Toulon, CNRS, IRD, MIO UM 110, Mediterranean Institute of Oceanography, Marseille, France, \\ ${ }^{2}$ Department of Earth, Ocean and Atmospheric Sciences, University of British Columbia, Vancouver, British Columbia, \\ Canada, ${ }^{3}$ Hakai Institute, Heriot Bay, British Columbia, Canada, ${ }^{4}$ Millennium Institute of Oceanography (IMO), University of \\ Concepcion, Concepción, Biobío, Chile
}

\begin{abstract}
The Gulf of Lion is an important area of deep convection, where intense winter vertical mixing brings nutrients up from deeper layers, promoting the largest bloom in the Mediterranean at the end of winter/early spring. The DEWEX program conducted cruises in February and April 2013 to investigate the ecosystem level impacts of deep water convection. Zooplankton data were collected through net sampling and imaging with an Underwater Vision Profiler. In winter, low zooplankton abundance and biomass were observed in the Deep Convection Zone (DCZ) and higher values on its periphery. In spring, this pattern reversed with high biomass in the DCZ and lower values on the periphery. On average for the whole area, the potential grazing impact was estimated to increase by one order of magnitude from winter to spring. In April, all areas except the DCZ incurred top-down control by zooplankton on the phytoplankton stock. In the $\mathrm{DCZ}$, the chlorophyll-a values remained high despite the high zooplankton biomass and carbon demand, indicating a sustained bottom-up control. The zooplankton community composition was comparable for both periods, typified by high copepod dominance, but with some differences between the DCZ and peripheral regions. In spring the DCZ was characterized by a strong increase in herbivorous species such as Centropages typicus and Calanus helgolandicus, and an increase in the number of large zooplankton individuals. Our study indicates that the DCZ is likely an area of both enhanced energy transfer to higher trophic levels and organic matter export in the North Western Mediterranean Sea.
\end{abstract}

\section{Introduction}

In the North Western Mediterranean Sea (NWMS hereinafter), the central part of the Provencal basin, off the Gulf of Lion (centered on $42^{\circ} \mathrm{N} 5^{\circ} \mathrm{E}-$ MEDOC area), is an important area of deep water formation [MEDOC GROUP, 1970]. The deep convection process occurs in late winter, driven primarily by the combination of the regional cyclonic circulation, and buoyancy loss resulting from the cold and dry northerly Mistral winds blowing out of the Rhone Valley over the Gulf of Lion [Millot and Taupier-Letage, 2005]. This dense water extends from the Gulf of Lion to the Ligurian Sea [Millot, 1990], and is largely delimited by the extent of the cyclonic gyre of the Liguro-Provencal basin, bounded to the north by the so-called Liguro- ProvencoCatalan Current (LPCC) and to the south by the North Balearic Front (NBF) which permanently fluctuates between modified Atlantic waters from the Algerian basin and the colder waters of the Liguro-Provencal basin.

Apart from its fundamental hydrological role in the Western Mediterranean Sea, the winter deep convection strongly affects the magnitude and spatial extent of new primary production. Nutrient rich deep waters mix with nutrient depleted upper layers and eventually replenish surface nutrients over a large area. These convection derived nutrients, augmented by factors such as frontal systems or Rhone River inputs, support the highest regional scale chlorophyll-a values (up to $3 \mu \mathrm{g} \mathrm{Chl-} a \mathrm{~L}^{-1}$ ) in the Mediterranean Sea [Estrada, 1996; D'Ortenzio and Ribera d'Alcalà, 2009]. Typically, a substantive spring bloom is observed in March in the deep convection zone, when surface stratification begins. The high primary productivity in the NWMS is expected to stimulate secondary productivity, with an expected high efficiency of energy transfer [Alcaraz, 1985], however observations of intermediate food-web levels such as zooplankton remain too scarce and spatially restricted [Siokou-Frangou et al., 2010] to validate this expectation on a regional scale. 


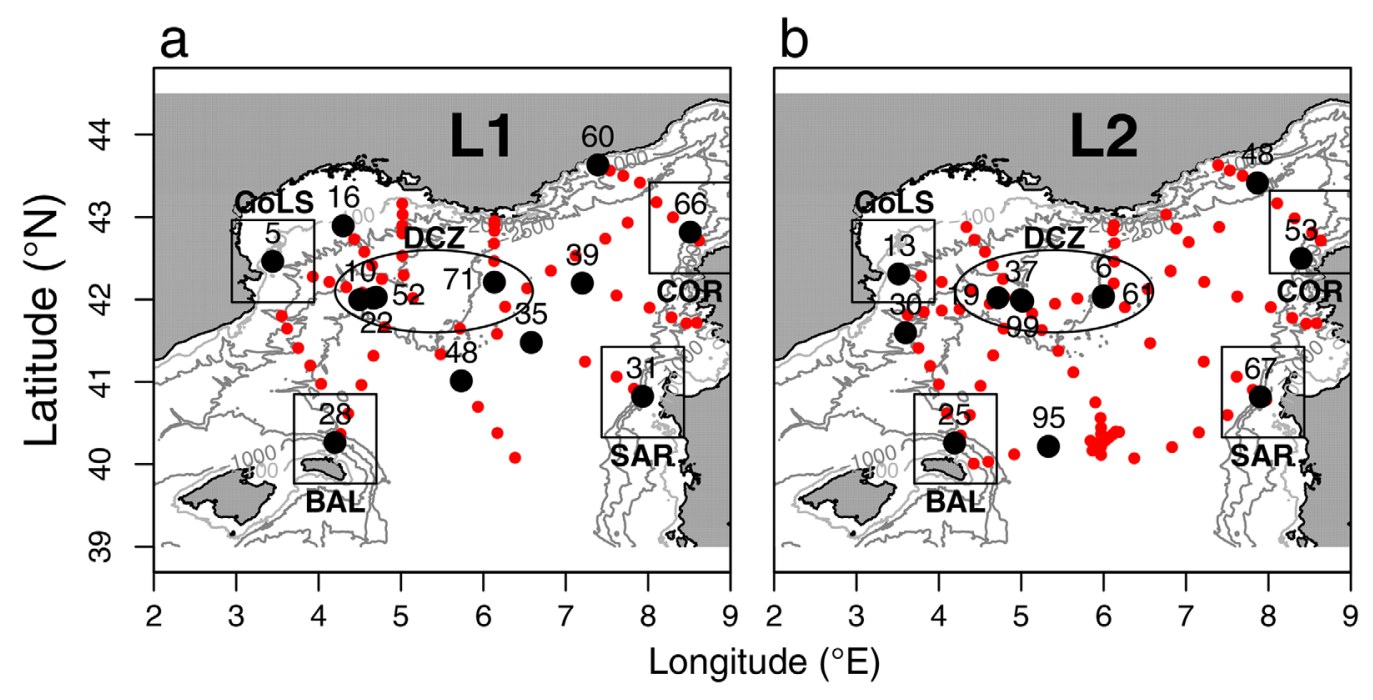

Figure 1. Map of the DEWEX study area with positions of the sampling stations for (a) L1 and (b) L2. Black dots: zooplankton net tows stations; red dots: CTD and UVP casts. Squares and ellipse zones: repeated stations across the two legs selected for seasonal comparisons, which define Zones Baleares (BAL), Shelf (GoLS), Convection (DCZ), Corsica (COR) and Sardinia (SAR).

Zooplankton biomass and abundance data in the NWMS are limited and with insufficient coverage to provide a clear spatial and temporal overview of the region. A few zooplankton time series exist for the NWMS: two coastal - in the Balearic Sea [Fernández de Puelles et al., 2003, 2004b] and Ligurian Sea [Molinero et al., 2005, 2008; García-Comas et al., 2011]; and one off-shore station (DYFAMED) in the Ligurian Sea [Berline et al., 2011]. A few shorter time series exist, such as a 3 year study off Marseille by Gaudy and Champalbert [1998]. Field surveys in the NWMS last generally for one to three weeks and are usually limited to subregions, such as the Gulf of Lion's continental shelf (Furnestin [1960]-summer; Gaudy et al. [2003]-winter and spring), Ligurian Sea (Pinca and Dallot [1995, 1997]-spring; Andersen et al. [2001]spring; McGehee et al. [2004]-summer), Balearic Sea (Fernández de Puelles et al. [2004a]-spring) and Catalan Sea (Sabatés et al. [1989]-spring to fall). Only one study focused on the deep convection zone, for two periods (1-15 March and 3-17 April 1969), but that study only analyzed zooplankton biomass [Nival et al., 1975].

In this context, the DEep Water formation EXperiment (DEWEX) program [Testor et al., 2016] aimed to significantly improve understanding of how deep convection and subsequent restratification affects the organization of the pelagic ecosystem, from physical processes through biogeochemistry and up to biological communities. The main goal of our study was to investigate the zooplankton community response to the transition from the deep water formation period to the stratification period, in terms of spatial distribution and composition. Two campaigns were conducted in 2013, the first in winter during the deep convection event, and the second in spring, during the spring bloom. These campaigns were short ( $<20$ days), allowing for pseudo-synoptic data mapping. In this paper, we present results on the hydrological and biological zooplankton environment, the bulk properties of zooplankton distribution, taxonomy and size composition, and estimate the zooplankton's potential grazing impact on phytoplankton.

\section{Materials and Methods}

\subsection{Study Area and Sampling Strategy}

The DEWEX cruises were conducted onboard R/V Le Suroît. The first leg (Leg 1, hereafter L1) was carried out from 3 to 21 February 2013 during the winter convection period, and the second leg (Leg 2, hereafter L2) from 5 to 24 April 2013 during the spring bloom. Both cruises had the same sampling track, covering the whole NWMS (Figure 1). The sampling grid comprised 76 stations on L1 and 100 stations on L2, and followed a star shape path spanning the cyclonic circulation of the basin. At every station, physical parameters were sampled using a CTD. 


\subsection{Environmental Data}

Temperature, salinity, and density were collected with a CTD (SeaBirdElectronics' 911+ technology) mounted on a rosette carrying 12 Niskin bottles of $12 \mathrm{~L}$. Dissolved oxygen concentration was measured using a SBE43 sensor and fluorescence was measured using a Chelsea fluorometer. Fluorescence was calibrated with the chlorophyll- $a$ concentration estimated from bottle water samples using HPLC [Uitz et al., 2009]. The depth of the mixed layer (MLD) was computed using the density difference criterion $\Delta \sigma_{\theta}=0.03 \mathrm{~kg}$ $\mathrm{m}^{-3}$ of De Boyer Montégut et al. [2004].

\subsection{Zooplankton Collection}

All zooplankton sampling was performed at night. Due to time and weather constraints 13 and 12 stations were sampled on L1 and L2 respectively. Samples were collected with a $70 \mathrm{~cm}$ mouth diameter Bongo Nets, fitted with a $120 \mu \mathrm{m}$ net with filtering cod-ends. The net was operated in vertical net hauls between $250 \mathrm{~m}$ and the surface at a speed of $1 \mathrm{~m} \mathrm{~s}^{-1}$. One cod-end was used for biomass measurements and the second was fixed directly after collection with buffered formalin at $10 \%$ final concentration, for taxonomic identification and size spectrum analyses. Sampled volume was determined assuming $100 \%$ filtration efficiency, by multiplying the surface of the net opening by the haul depth, i.e., $0.38 \mathrm{~m}^{2} \times 250 \mathrm{~m}=95 \mathrm{~m}^{3}$. As such our abundance calculations were likely underestimated.

\subsection{Zooplankton Sample Processing}

2.4.1. Biomass Measurement and Taxonomy Identification

The biomass sample was processed onboard. After collection each sample was filtered onto a preweighed GF/F filter $(47 \mathrm{~mm})$ and oven dried at $60^{\circ} \mathrm{C}$ for 2 days. The zooplankton dry weight $(\mathrm{mg})$ was calculated as the difference between the weight of the filter + sample and the weight of the filter. Dry weight was divided by the volume filtered to estimate biomass concentration (in $\mathrm{mg} \mathrm{DW} \mathrm{m}^{-3}$ ). The taxonomic composition was determined for each formalin sample. Samples were split using a Motoda box, and at least 100 individuals of the more abundant taxa were counted in each subsample under a dissecting microscope, a LEICA MZ6. Rare taxa were enumerated from the whole sample. Species/genus identification was made according to Rose [1933], Tregouboff and Rose [1957], and Razouls et al. [2005]. The abundance of the various taxa (groups, genera or species) was divided by the sample volume to get concentration of individuals per cubic meter (ind. $\mathrm{m}^{-3}$ ).

\subsubsection{Imaging and Size Structure Analysis}

\subsubsection{Imaging and Processing}

Samples were digitized with the ZooScan digital imaging system [Gorsky et al., 2010] to determine the size structure of the zooplankton communities. Each sample was divided in 2 fractions $(<1000$ and $>1000$ $\mu \mathrm{m}$ ) for better representation of rare large organisms in the scanned subsample [Vandromme et al., 2012]. Each fraction was split using a Motoda box until it contained approximately 1000 objects. The resulting samples were poured onto the scanning cell and zooplankton organisms were manually separated with a wooden spine in order to avoid overlapping organisms. After scanning, each image was processed using ZooProcess [Gorsky et al., 2010], which is embedded in the ImageJ image analysis software [Rasband, 2005]. Only objects having an equivalent spherical diameter (ESD) of $>300 \mu \mathrm{m}$ were detected and processed [Gorsky et al., 2010]. Finally, Plankton Identifier (http://www.obs-vlfr.fr/ gaspari/Plankton_Identifier/ index.php) was used for automatic classification of zooplankton into 9 categories: calanoidea like copepods, non calanoidea like copepods, appendicularia, chaetognatha, other crustacean, various zooplankton, detritus, fibers and blurred images. Results of the automatic classification were manually validated to ensure that every vignette in each one of the 9 categories corresponded to the category that was automatically assigned. Zooplankton abundance (ind $\mathrm{m}^{-3}$ ) was calculated from the number of validated vignettes in Zooscan samples, taking into account the scanned fraction and the sampled volume from the net tows.

\subsubsection{Size Spectra}

The shape of the size spectra is a key ecological indicator of the dynamics of the zooplankton community [Krupica et al., 2012]. The slope of the NBSS reflects the balance between the abundance of small and large individuals, a steep slope corresponding to higher proportion of small individuals and vice-versa. Log-normalized biomass size spectra (NBSS) were calculated for each sample, following Herman and Harvey [2006]. First, the biovolume was calculated by applying equation (1): 


$$
\text { BioV }=\frac{4}{3} * \frac{\text { Area }}{\sqrt{\text { Ratio }}} * \sqrt{\frac{\text { Area }}{\pi}}
$$

where BioV is the biovolume, Area is the pixel area of the organisms in the image, and Ratio is the ratio between the major axis and the minor axis of each organism. The biovolume is converted into wet weight (WW), assuming $1 \mathrm{~mm}^{-3}$ was equivalent to $1 \mathrm{mg} \mathrm{WW}$ [Wiebe et al., 1975].

The NBSS were constructed for 30 log based WW size bins and the total WW biomass for each bin divided by the bin width. Slope and intercept values for the NBSS of each sample were estimated from linear regression of the size spectra from minimum size $(0.3 \mathrm{~mm})$ to maximum size $(1.1 \mathrm{~mm})$.

\subsubsection{In Situ Imaging}

The Underwater Vision Profiler 5 (UVP) [Picheral et al., 2010] is an autonomous underwater imaging system designed and constructed to quantify large $(>100 \mu \mathrm{m})$ aggregates and zooplankton. It can be mounted on a standard rosette frame and interfaced with the CTD. The smaller size limit (100 $\mu \mathrm{m})$ is fixed by the optical resolution of the instrument, whereas the larger size limit $(26 \mathrm{~mm})$ is determined by the volume of water illuminated per image.

In this study, the UVP was mounted in an external frame attached to the rosette, and deployed at every sampling station during day and night. Due to technical problems 54 stations were analyzed from L1 and 78 from L2. All particles larger than $105 \mu \mathrm{m}$ were processed, and the vignettes larger than $600 \mu \mathrm{m}$ were extracted. For image analysis, vignettes were uploaded to the EcoTaxa [Picheral et al., 2015] online tool and classified using the integrated automatic classification. Only the copepod category was manually validated, and copepod abundance was calculated as the number of copepods in the first $250 \mathrm{~m}$ of the water column, and divided by the sampled volume to estimate ind. $\mathrm{m}^{-3}$. For each profile, the sampled volume was computed by multiplying the number of images taken across the samples depth range by the individual volume per image. Over all profiles the average sampled volume was $1.96 \pm 0.27 \mathrm{~m}^{3}$.

Due to the small sampled volume of the UVP $\left(1.96 \mathrm{~m}^{3}\right.$ per profile versus $95 \mathrm{~m}^{3}$ per haul with nets on average) copepod counts likely underestimated real densities. Before using UVP copepod counts as a proxy of copepod abundance to study their distribution gradients, we first determined whether the underestimation was consistent for all stations by comparing UVP copepod counts with counts of copepods larger than 600 $\mu \mathrm{m}$ in the Zooscan samples. Since UVP casts were done during the day and the night, a Kruskal-Wallis test was preformed to asses sampling time effect on copepod abundance.

\subsection{Data Analysis}

Hierarchical clustering was used to explore spatial patterns of the environmental variables temperature, salinity, dissolved oxygen, and chlorophyll-a, using depth-average values between 0 and $250 \mathrm{~m}$, to be consistent with the net haul depth. The MLD was included in the calculations. Similarity between stations was calculated using Euclidean distance and clustering was performed using Ward's linkage. The CalinskiHarabasz criterion [Calinski and Harabasz, 1974] was used to assess the optimal number of clusters.

Canonical correlations analyses (CCA) were used to explore the relationships between environmental variables (depth-average of temperature, salinity, dissolved oxygen, and chlorophyll- $a$ ) and zooplankton variables (copepod taxonomic composition and copepod size distribution). This analysis was repeated for each cruise separately. Rare species were removed prior to analysis, and only species that contributed at least $1 \%$ to the abundance, and were present in more than 2 samples were kept. The CCA analyses were performed on log transformed abundance data. Scaling 3 was used in all triplots, in which both sites and species are scaled proportional to eigenvalues on all dimensions [Oksanen et al., 2016]. Spearman rank correlation coefficients $\left(r_{s}\right)$ were calculated to assess simple relationships between zooplankton and environmental variables.

To assess seasonal differences in zooplankton community composition, we selected five zones where repeated net sampling stations were carried out over the two legs: the shelf in the western part of the Gulf of Lion (GoLS; L1- St 5 and L2-St 13); Baleares in the northern part of Menorca Island (BAL, L1-St 28 and L2-St 25); Sardinia in the west part of Sardinia Island (SAR, St L1 31 and St L2 67); Corsica in the western part of Corsica Island (COR, L1-St 66 and L2-St 53); and the Deep Convection Zone (DCZ, L1-St 10,22, 5271 and L2-St 6, 19, 37, 61, 99). Boxplots were used to show differences in abundance, biomass, and diversity between sampling periods and zones. 
To better understand the changes in the community structure, Rank Frequency Diagrams were constructed by plotting the ranks of all species on the $x$-axis (in decreasing order of frequency) against their logarithmic frequency value on the $y$ axis. Copepod diversity was calculated using the Shannon-Wiener diversity index (based on natural logarithms) with PRIMER 6.0 software [Clarke and Warwick, 1994], and all other analyses were performed using R freeware (www.r-project.org).

\subsection{Zooplankton Carbon Demand}

The copepods carbon demand (ZCD) was computed based on estimates of biomass from Zooscan samples and estimates of growth rate from Zhou et al. [2010] following Vandromme et al. [2011]:

$$
\mathrm{ZCD}\left(\mathrm{mg} \mathrm{C} \mathrm{m} \mathrm{m}^{-3} \mathrm{~d}^{-1}\right)=\text { Ration } \mathrm{B}_{\mathrm{zoo}}
$$

where $\mathrm{B}_{\mathrm{zoo}}$ is the biomass of copepods in $\mathrm{mg} \mathrm{C} \mathrm{m}^{-3}$, calculated using area-carbon weight relationships from Lehette and Hernández-León [2009] for subtropical copepods. As in Nival et al. [1975], Ration is defined as the amount of food consumed per unit of biomass, calculated as:

$$
\operatorname{Ration}\left(\mathrm{d}^{-1}\right)=\frac{(g z+r)}{A}
$$

where $g z$ is the growth rate, $r$ is the weight specific respiration and $A$ is assimilation efficiency. $g z$ was calculated following Zhou et al. [2010]:

$$
g z\left(w, T, C_{a}\right)=0.033\left(\frac{C_{a}}{C_{a}+205 e^{-0.125 T}}\right) e^{0.09 T} w^{-0.06}
$$

as a function of sea water temperature $\left(T,{ }^{\circ} \mathrm{C}\right)$, food availability $\left(\mathrm{C}_{a}, \mathrm{mg} \mathrm{C} \mathrm{m}{ }^{-3}\right.$, estimated from Chl-a), and weight of individuals $(w, \mathrm{mg} C)$. We consider here that food is only phytoplankton following Calbet et al. [1996]. Following Alcaraz et al. [2007] and Nival et al. [1975], values $r$ and A were $0.16 d^{-1}$ and 0.7 respectively. $g z$ was computed at every depth from the surface to $250 \mathrm{~m}$, and $\mathrm{B}_{\mathrm{zoo}}$ was the average value. We compared ZCD to the phytoplankton stock, converted to carbon assuming a C:Chl-a ratio of 30:1 [Delgado et al., 1992], to estimate the potential clearance of phytoplankton by copepods.

\section{Results}

\subsection{Spatial Patterns in the Environment}

Following cluster analysis of environmental variables the Calinski-Harabasz criterion identified four clusters for L1 and three clusters for L2. Three clusters were retained for both legs to be consistent between periods, and because the fourth cluster separated a few station of the peripheral zone (Figure 2).

For L1 (winter convection), Cluster 1 (green, Figures 2a and 2b) grouped 38 stations located in the central part of the deep convection area. These stations were characterized by vertically homogenous temperature and salinity (Figures $3 a$ and $3 b$ ), showing the deep mixing signature (mean mixed layer depth $=2293 \mathrm{~m}$, Figure 3e), and by low chlorophyll- $a$ and dissolved oxygen values (Figures $3 c$ and $3 \mathrm{~d}$ ). Conversely, the stations grouped in Clusters 2 and 3 were characterized by a stratified water column (average MLD $=119 \mathrm{~m}$, Figure 3 e). Cluster 2 (red in Figures $2 \mathrm{a}$ and $2 \mathrm{~b}$ ) comprised 30 stations located on the periphery of the deep convection area, characterized by higher temperature, chlorophyll- $a$ and dissolved oxygen, and lower salinity than Cluster 1 (red boxplots in Figures 3a-3d). Cluster 3 (blue, Figures $2 a$ and 2b) was predominantly composed of stations located on the shelf break, with one station in the southern part of the survey region. These 7 stations were characterized by a broad range of temperature, the lowest salinity during L1 and the highest values of oxygen and chlorophyll- $a$ (Figures 3a-3d). Vertical profiles from each cluster can be found in supporting information.

During L2 (spring bloom), stratification occurred over the entire survey area. Cluster 1 (magenta in Figures $2 \mathrm{c}$ and $2 \mathrm{~d}$ ) grouped 44 stations located in the central part of the area, characterized by high chlorophyll- $a$ concentrations, high salinity and low temperature (magenta boxplots in Figures 3i, 3g, and $3 \mathrm{f}$ ). The stations in clusters 2 and 3 were characterized by lower chlorophyll-a concentration (Figure 3i). Cluster 2 (yellow, Figures $2 \mathrm{c}$ and $2 \mathrm{~d}$ ) and Cluster 3 (cyan, Figures 2 and 3) comprised 30 and 26 stations respectively. Cluster 3 
a

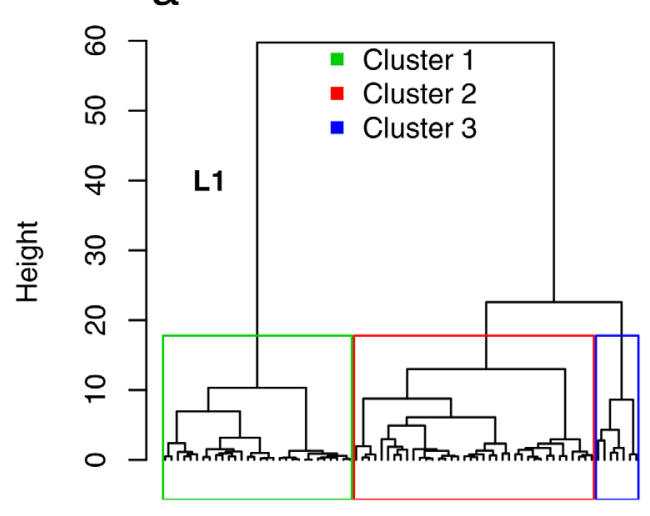

C

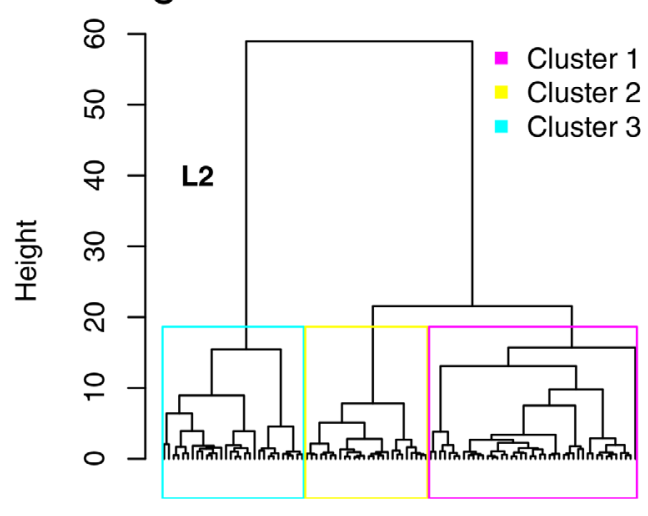

Stations b
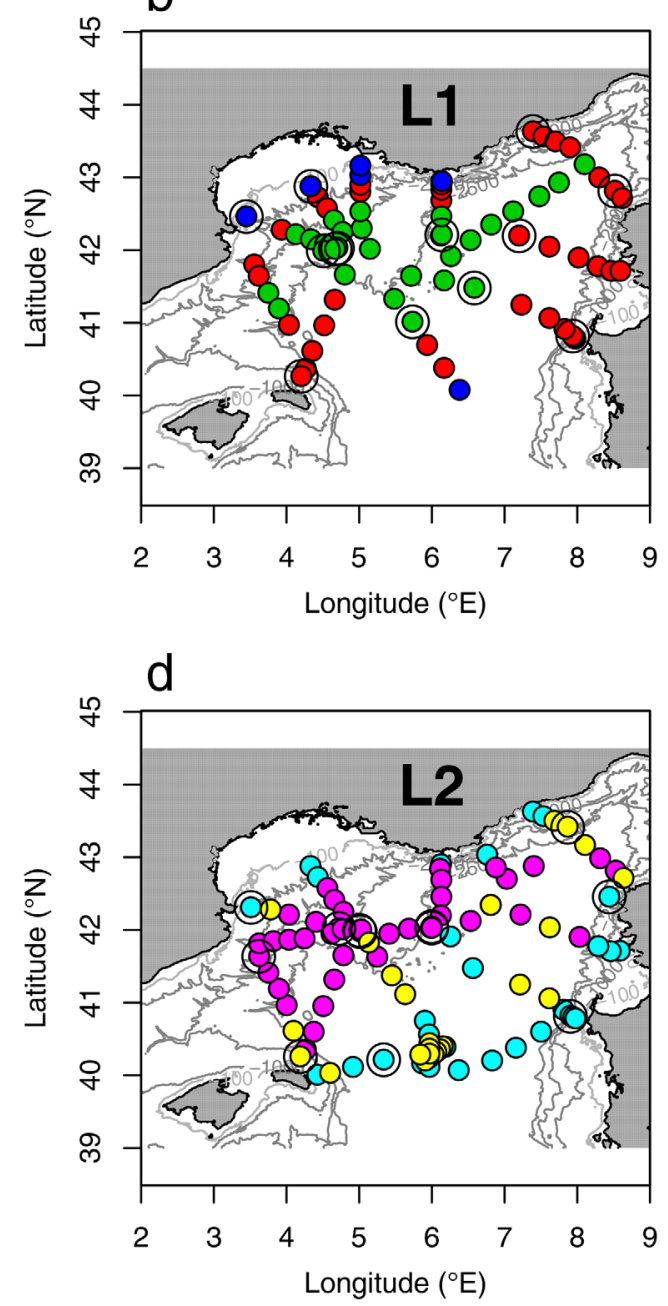

Figure 2. Hierarchical clustering of environmental variables, using Ward clustering algorithm on Euclidian distance, for (top) L1 and (bottom) L2. ( $a, c)$ Cluster dendrogram, with color frames highlighting the 3 main clusters. (b, d) Map of the stations identified by clustering (same colors as Figures 2a and 2c). Large open circles indicate sampled net stations. Cluster from L1 and L2 have no relationship.

was characterized by higher oxygen and lower salinity levels than Cluster 2 (cyan and yellow boxplots in Figure 3).

\subsection{Spatial Distribution of Zooplankton Abundance, Biomass, and Size Structure During the Winter and Spring Surveys}

During L1 zooplankton biomass (Figure 4a) ranged from 1.98 (L1-St 52, DCZ) to $42.31 \mathrm{mg} \mathrm{DW} \mathrm{m}^{-3}$ (L1-St 39), with an average of $12.3 \pm 12.7 \mathrm{mg} \mathrm{DW} \mathrm{m}^{-3}$. During L2 (Figure 4b) biomass ranged from 13.9 (L2-St 48) to $197.8 \mathrm{mg} \mathrm{DW} \mathrm{m}^{-3}$ (L2-St 61, DCZ), with an average of $64.59 \pm 59.11 \mathrm{mg} \mathrm{DW} \mathrm{m}^{-3}$. During L1 zooplankton biomass was significantly negatively correlated with $\operatorname{MLD}\left(r_{s}=-0.75, p=0.003\right)$, while during L2 biomass presented a significant positive correlation with chlorophyll- $a$ concentrations $\left(r_{s}=0.76, p=0.006\right)$. The central part of the DCZ had the highest biomass change between L1 and L2.

Zooplankton abundances ranged from 21 (L1-St 35) to 2548 ind. $\mathrm{m}^{-3}$ (L1-St 39), with a mean of $608 \pm$ 764 ind. $\mathrm{m}^{-3}$ during L1 (Figure 4c), and from 850 ind. $\mathrm{m}^{-3}$ (L2-St 19, near the DCZ) to 7205 ind. $\mathrm{m}^{-3}$ (L2-St 13 , GoLS), with a mean of $3668 \pm 2502$ ind. $\mathrm{m}^{-3}$, during L2 (Figure $4 \mathrm{~d}$ ). The spatial distribution of abundance was similar to biomass distributions during both legs. On average, an increase in terms of both biomass and abundance was observed from L1 to L2 (Figures 5a and 5b). Biomass values were on average 5 times higher on L2 than on L1. However, this increase depended on the geographical area: at stations in the vicinity of BAL, COR and SAR Zones biomass approximately doubled between $L 1$ and L2, whereas GoLS 

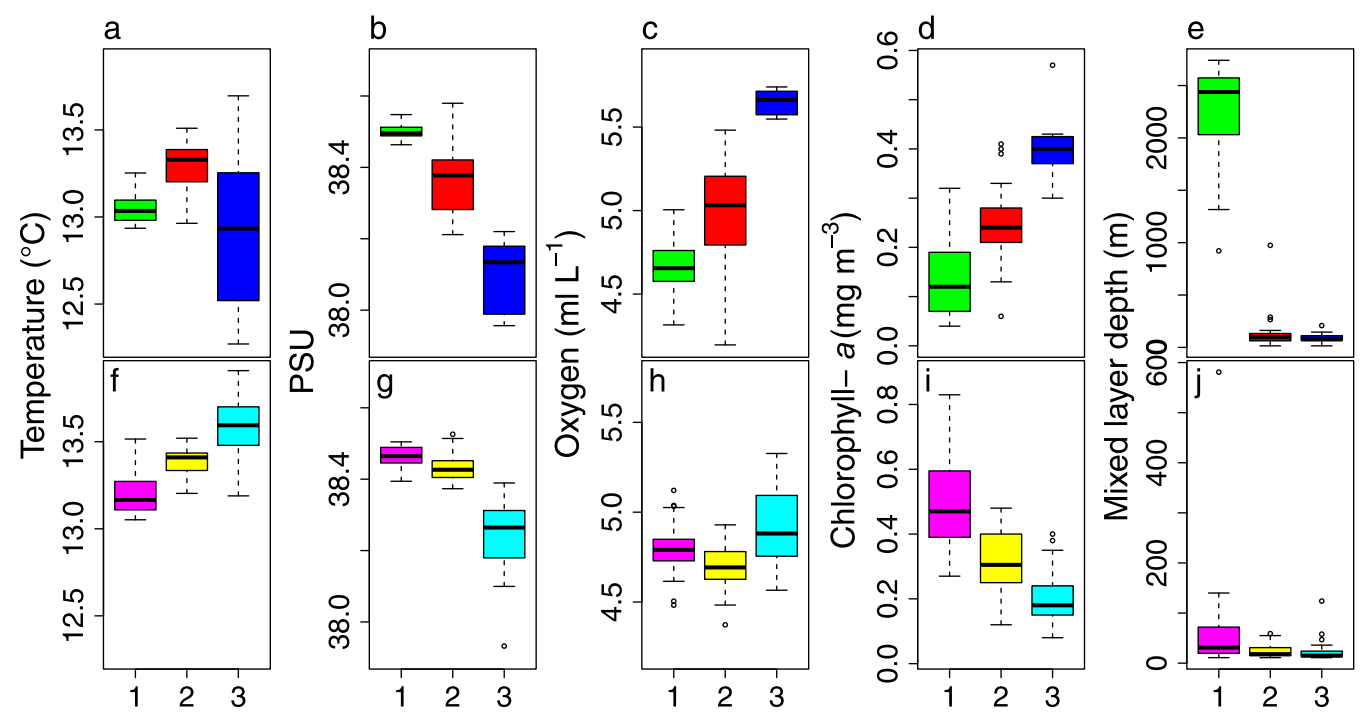

Figure 3. Boxplot of temperature, salinity, oxygen and chlorophyll-a within the upper $250 \mathrm{~m}$ of the water column, and depth of the mixed layer, for (top) (a-e) L1 and L2 (bottom) ( $\mathrm{f}-\mathrm{j})$ following clusters defined in Figure 2 (same colors).

and DCZ stations biomass increased by approximately one order of magnitude. Abundance values were also higher on L2, with the GoLS (St13) and SAR (St 67) Zones having the highest differences.

From UVP images, objects of ESD $>600 \mu \mathrm{m}$ and identified as copepods were used as a relative index for comparison with copepod abundance of ESD $>600 \mu \mathrm{m}$ in Zooscan samples. The UVP counts of copepods were too few in L1 to allow a spatial analysis (copepods were only detected at 8 stations out of 75). For L2, copepod UVP counts ranged from 0 to 81 ind. $\mathrm{m}^{-3}$. A regression analysis shows that UVP counts in the upper $250 \mathrm{~m}$ were strongly correlated with net-based abundance estimates (Figure 6; slope $=0.003$, $\mathrm{R}^{2}=0.86, \mathrm{p}<0.001, \mathrm{n}=9$ ). Accordingly we used UVP counts as a proxy for large copepod abundance in the upper $250 \mathrm{~m}$. UVP copepod counts did not vary significantly between day and night casts (Kruskal-Wallis test, $p=0.12$ ), so we considered that they could be analyzed together. Stations with UVP counts larger than 20 ind. $\mathrm{m}^{-3}$ were situated in the central part of the sampled area (Figure 7) characterized by the highest chlorophyll- $a$ (see magenta circles and cluster frame on Figures $2 \mathrm{c}$ and $2 \mathrm{~d}$ ). UVP abundance showed a negative correlation with temperature $\left(r_{s}=-0.69, p<0.001\right)$ and a positive correlation with chlorophyll- $a$ concentrations $\left(\mathrm{r}_{\mathrm{s}}=0.60, \mathrm{p}<0.001\right)$.

The slopes of the NBSS did not show a clear spatial pattern during L1 (Figure 4e), ranging from -2.2 (L1-St 39) to -0.55 (L1-St 31, SAR). During L2 (Figure 4f), the highest and lowest slopes were -1.7 (L2-St 13, GoLS) and -0.68 (L2-St 99, in the DCZ) respectively. The DCZ was characterized by flat slopes ( -0.76 on average), with higher values on the shelf edge and in the coastal stations. Seasonal changes in NBSS slopes varied regionally (Figure 4c): in the GoLS and SAR Zones, the NBSS slopes were steeper, changing from -0.6 to -1.7 and -0.5 to -1.55 between $L 1$ and $L 2$ respectively, indicating a higher amount of small organisms during L2; in the DCZ and COR Zones, the NBSS slopes becomes flatter (from -1.1 to -0.76 and from -1.5 to -0.98 respectively) between $L 1$ and $L 2$, indicating growth from small to larger forms. The BAL Zone (L1St 28 and L2-St 25) was the only zone that demonstrated no slope change between legs (-1.2). Over the whole sampled region, the median NBSS values slightly decreased ( -1.3 for L1 and -0.97 for L2).

\subsection{Zooplankton Community Composition and Distribution 3.3.1. Zooplankton Diversity}

A total of 60 zooplankton taxa were identified from the two legs, including 30 copepods genera or species (plus miscellaneous nauplii and copepodites), 21 other holoplanktonic taxa, and 7 meroplankton taxa. The zooplankton community was similar for both periods, mainly dominated by copepods ( $\sim 95 \%$ Table 1, Figure 8). Calanoid copepods were the most abundant group (77\% in L1 and $84 \%$ in L2). Based on this taxonomic analysis, the mean taxonomic richness of the zooplankton community increased slightly from $32 \pm 5$ 

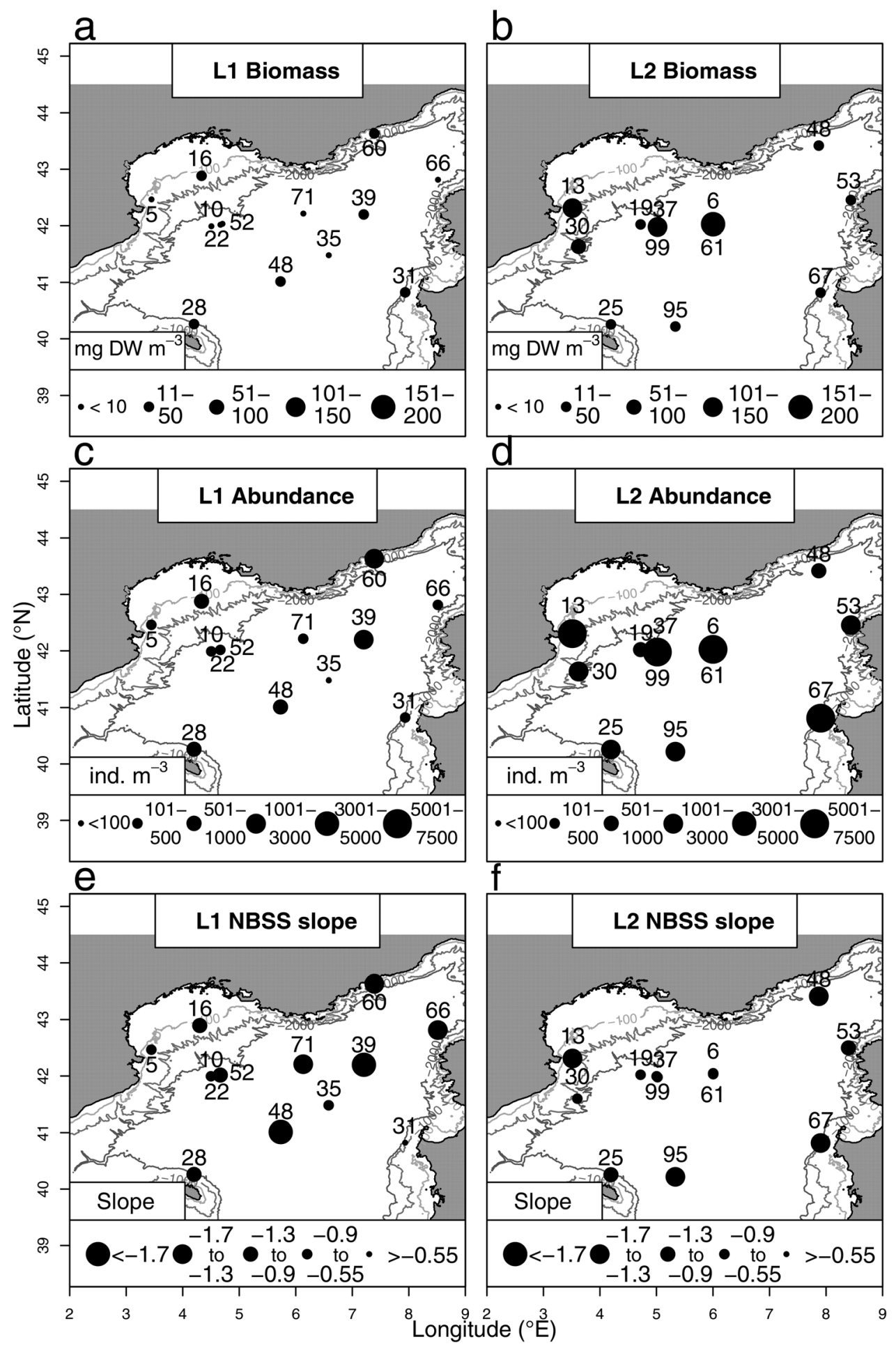

Figure 4. Spatial distributions (left: $L 1$ and right: $L 2)$ of zooplankton $(a, b)$ biomasses $\left(m g ~ D W ~ m^{-3}\right),(c, d)$ abundances (ind. $\left.m^{-3}\right)$ and $(e, f)$ NBSS slopes.

on L1 to $37 \pm 6$ on L2. The Shannon diversity index for copepods decreased slightly between the two periods for the whole area, and for the DCZ, GoLS, COR and SAR Zones (Figure 9). The diversity decrease was strongest in the GoLS Zone. The BAL Zone was the only region where diversity increased from L1 and $\mathrm{L} 2$. 

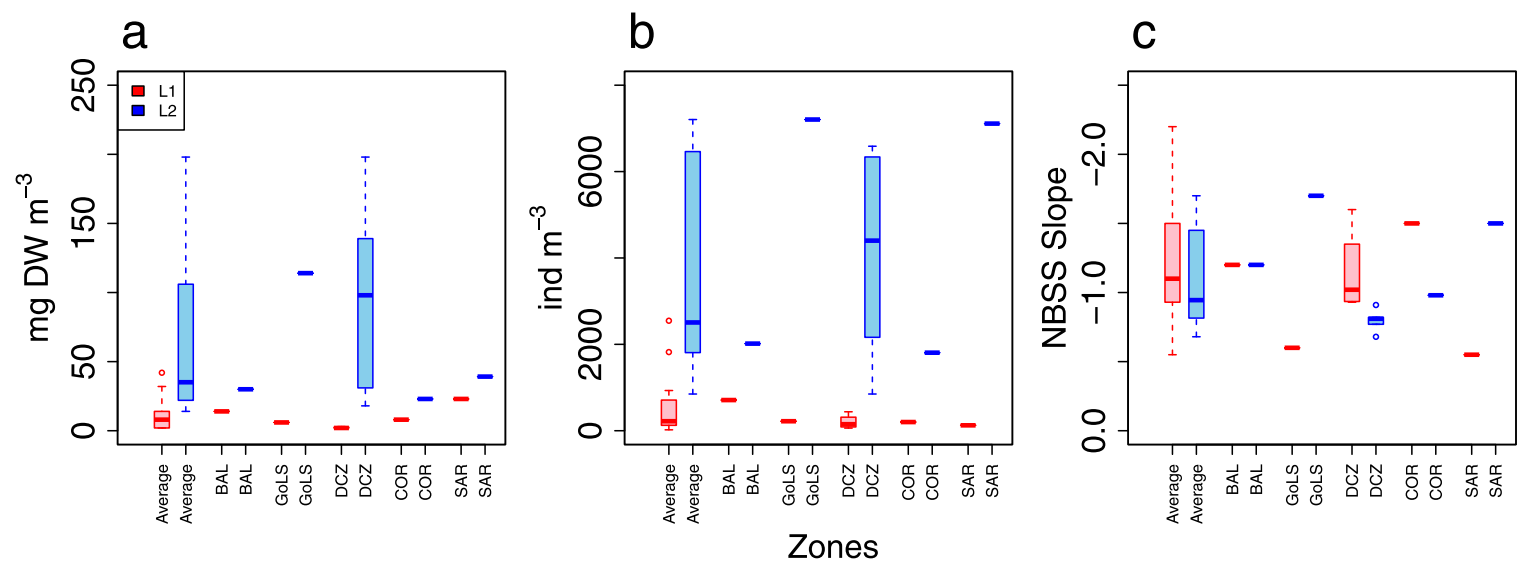

Figure 5. Changes in (a) biomass ( $\mathrm{mg} \mathrm{DW} \mathrm{m}^{-3}$ ), (b) Abundance (ind. $\mathrm{m}^{-3}$ ) and (c) NBSS slope between L1 and L2, in the five Zones defined in Figure 1 .

In the "rank-frequencies" diagrams grouping all stations by leg (Figure 8a), Clausocalanus/Paracalanus spp. was the dominant taxa (more than $60 \%$ ), followed by Oithona spp., in both periods. The third rank changed from Oncaea spp. on L1 to Centropages typicus on L2. Calanus helgolandicus, Centropages typicus, Calocalanus spp., Clausocalanus/Paracalanus spp, Microsetella, Oithona spp. and Oncaea spp. were the most frequent taxa found in the top 5 ranks over all regions for both periods (Figures 8b-8f). Euchaeta/Paraeuchaeta spp, Pleuromamma gracilis and Neocalanus gracilis were among the 5 most abundant taxa in some zones during L1, whereas Corycaeus/Farranula spp. were not in the top 5 ranks during L1, but appeared within these ranks at some stations during L2. Some species are important in specific zones: such as Calocalanus spp, ranked $3^{\text {rd }}$ in BAL, Oncaea spp. ranked $3^{\text {rd }}$ in the GoLS and DCZ zones, Microsetella spp. ranked $3^{\text {rd }}$ in COR and Calanus helgolandicus ranked $3^{\text {rd }}$ in SAR during L1. Finally, during L2, Centropages typicus was ranked $3^{\text {rd }}$ in BAL, DCZ and SAR Zones, Calanus helgolandicus ranked $3^{\text {rd }}$ in COR, and Calocalanus spp. ranked $3^{\text {rd }}$ in the GoLS Zone.

Important taxonomic groups other than copepods were Appendicularians, which increased slightly in numbers over the whole area from $L 1$ to $L 2$, and Euphausids, dominated by young stages produced during $L 2$ in the DCZ and along the Sardinia coast.

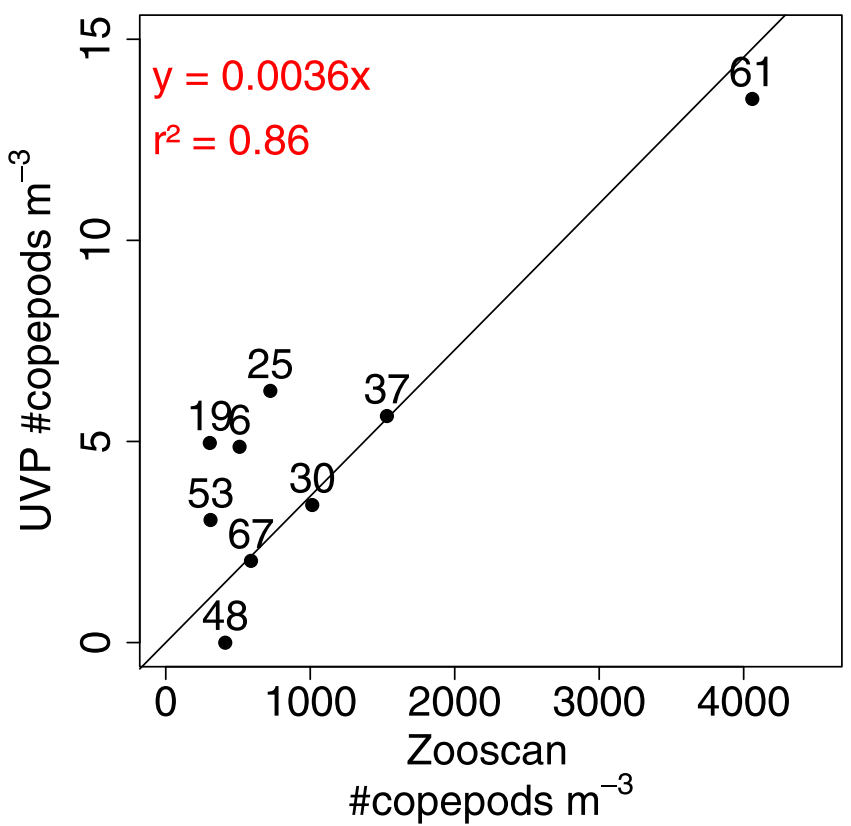

Figure 6. Comparison of copepod $(>600 \mu \mathrm{m})$ counts between ZooScan and UVP.

\subsubsection{Spatial Distribution of Key Taxa}

The spatial distributions of the key copepod taxa over the two legs are shown in Figure 10. The key taxa were defined as those being the most abundant (Clausocalanus/Paracalanus spp., Oithona spp., Oncaea spp. and Centropages typicus) and those differing from the average distribution (taxa departing from the CCA axes origin Figure 11).

Clausocalanus/Paracalanus spp, and Oithona spp. constituted the bulk of the copepod community from winter to spring. The abundance of these taxa strongly increased between L1 and L2, particularly in the DCZ, GoLS and SAR Zones, with the largest increase for Clausocalanus/Paracalanus spp. Observed in the DCZ (Figures 10a-10d). Oncaea spp. increased in abundance between L1 


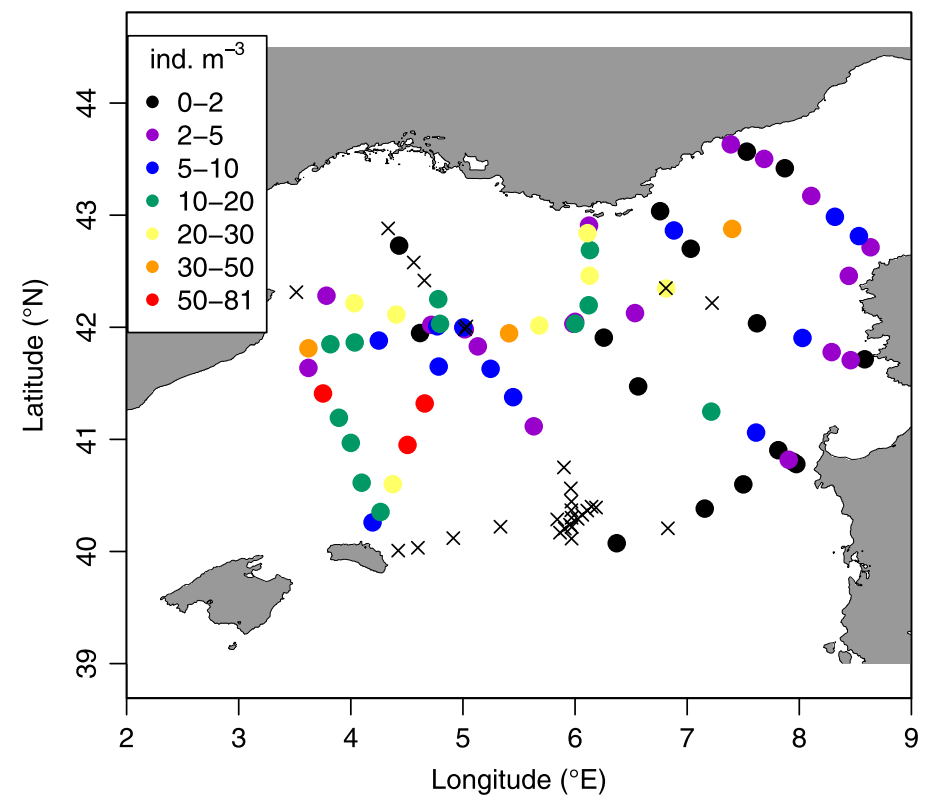

Figure 7. Spatial distribution of average copepod concentrations (ind. $\mathrm{m}^{-3}$ ) in the upper $250 \mathrm{~m}$ of the water column as detected by the UVP. Crosses represent stations with no UVP data. and L2, but with no clear spatial pattern (Figures 10e and 10f). C. typicus and Calanus helgolandicus were absent or in very low abundance during L1 and strongly increased during L2, particularly in the DCZ (Figures 10g-10j). On the contrary, Euterpina acutifrons and Mormonilla spp. decreased in abundance between $\mathrm{L} 1$ and $\mathrm{L} 2$, and were almost absent in the DCZ on L2 with the exception of St 13 for Mormonilla spp. (Figures 10k-10n).

\subsection{Relationship Between the Copepod Community Composition and} Environmental Conditions The relationship between the copepod community composition and environmental variable was analyzed using CCA (Figure 11).

\begin{tabular}{|c|c|c|c|c|c|c|}
\hline Taxa & Symbol & L1(\%) & L2(\%) & Taxa & L1(\%) & L2(\%) \\
\hline Copepods & & 95.31 & 95.13 & Holoplankton & 0.76 & 1.01 \\
\hline Order Calanoida & & 77.19 & 84.66 & Amphipoda & 0.01 & 0.01 \\
\hline Acartia spp. & (Aca) & 0.13 & 0.22 & Appendicularia & 0.25 & 0.17 \\
\hline Aetideus spp. & (Aet) & 0.03 & 0.00 & Chaetognatha & 0.04 & 0.01 \\
\hline Calanus helgolandicus & (C.hel) & 1.16 & 1.87 & Cladocera & 0.01 & 0.01 \\
\hline Calocalanus spp. & (Calo) & 0.69 & 0.48 & Doliolids & 0.00 & 0.00 \\
\hline Candacea spp. & (Cand) & 0.06 & 0.02 & Euphausiids & 0.23 & 0.52 \\
\hline Centropages typicus & (C.typ) & 0.44 & 2.41 & Isopods & 0.02 & 0.01 \\
\hline Clauso/Paracalanus spp. & $(\mathrm{Cl} / \mathrm{Pa})$ & 69.67 & 69.85 & Ostracods & 0.06 & 0.05 \\
\hline Eucalanus spp. & (Euc) & 0.01 & 0.01 & Pelagia noctiluca & 0.00 & 0.00 \\
\hline Euchaeta/Paraeuchaeta spp. & $(\mathrm{Eu} / \mathrm{Pa})$ & 0.21 & 0.04 & Pteropoda & 0.02 & 0.03 \\
\hline Euchirella rostrata & (Eu.r) & 0.07 & 0.14 & Pyrosoma & 0.01 & 0.00 \\
\hline Euchirella messinensis & (Eu.m) & 0.02 & 0.00 & Radiolaria & 0.01 & 0.00 \\
\hline Haloptilus spp. & (Halo) & 0.01 & 0.00 & Salps & 0.04 & 0.09 \\
\hline Heterorhabdus spp. & (Hete) & 0.08 & 0.02 & Siphonophora & 0.06 & 0.10 \\
\hline Lucicutia spp. & (Luci) & 0.04 & 0.01 & Velella velella & 0.00 & 0.00 \\
\hline Mecynocera spp. & (Mecy) & 0.05 & 0.02 & Other Holoplankton & 0.01 & 0.01 \\
\hline Mesocalanus tenuicornis & (Meso) & 0.00 & 0.00 & & & \\
\hline Nannocalanus minor & (Nann) & 0.17 & 0.04 & Meroplankton & 0.40 & 0.17 \\
\hline Neocalanus gracilis & (Neo) & 0.14 & 0.04 & Decapod larvae & 0.18 & 0.02 \\
\hline Pleuromamma abdominalis & (Ple.a) & 0.16 & 0.02 & Fish & 0.15 & 0.02 \\
\hline Pleuromamma gracilis & (Ple.g) & 0.43 & 0.09 & Gastropod larvae & 0.01 & 0.03 \\
\hline Pleuromamma robusta & (Ple.r) & 0.01 & 0.00 & Lamellibranch larvae & 0.02 & 0.02 \\
\hline Spinocalanus spp. & (Spin) & 0.00 & 0.00 & Polychaete larvae & 0.04 & 0.08 \\
\hline Temora stylifera & (T.sty) & 0.07 & 0.01 & Other Meroplankton & 0.01 & 0.00 \\
\hline Order Cyclopoida & & 17 & 10.1 & & & \\
\hline Corycaeus/Farranula spp. & $(\mathrm{Co} / \mathrm{Fa})$ & 0.3 & 0.16 & & & \\
\hline Oithona spp. & (Oith) & 14.1 & 9.61 & & & \\
\hline Oncaea spp. & (Onca) & 2.6 & 0.33 & & & \\
\hline Order Harpacticoida & & 1.03 & 0.36 & & & \\
\hline Clytemnestra spp. & (Cly) & 0.04 & 0.02 & & & \\
\hline Euterpina acutifrons & (Eute) & 0.33 & 0.02 & & & \\
\hline Microsetella spp. & (Micro) & 0.66 & 0.32 & & & \\
\hline \multicolumn{7}{|l|}{ Order Mormonilloida } \\
\hline Mormonilla spp. & (Morm) & 0.09 & 0.00 & & & \\
\hline Unidentified Copepodites & & 3.55 & 9.37 & & & \\
\hline Copepod Nauplii & & 3.51 & 3.68 & & & \\
\hline
\end{tabular}




\section{QDAU Journal of Geophysical Research: Oceans}
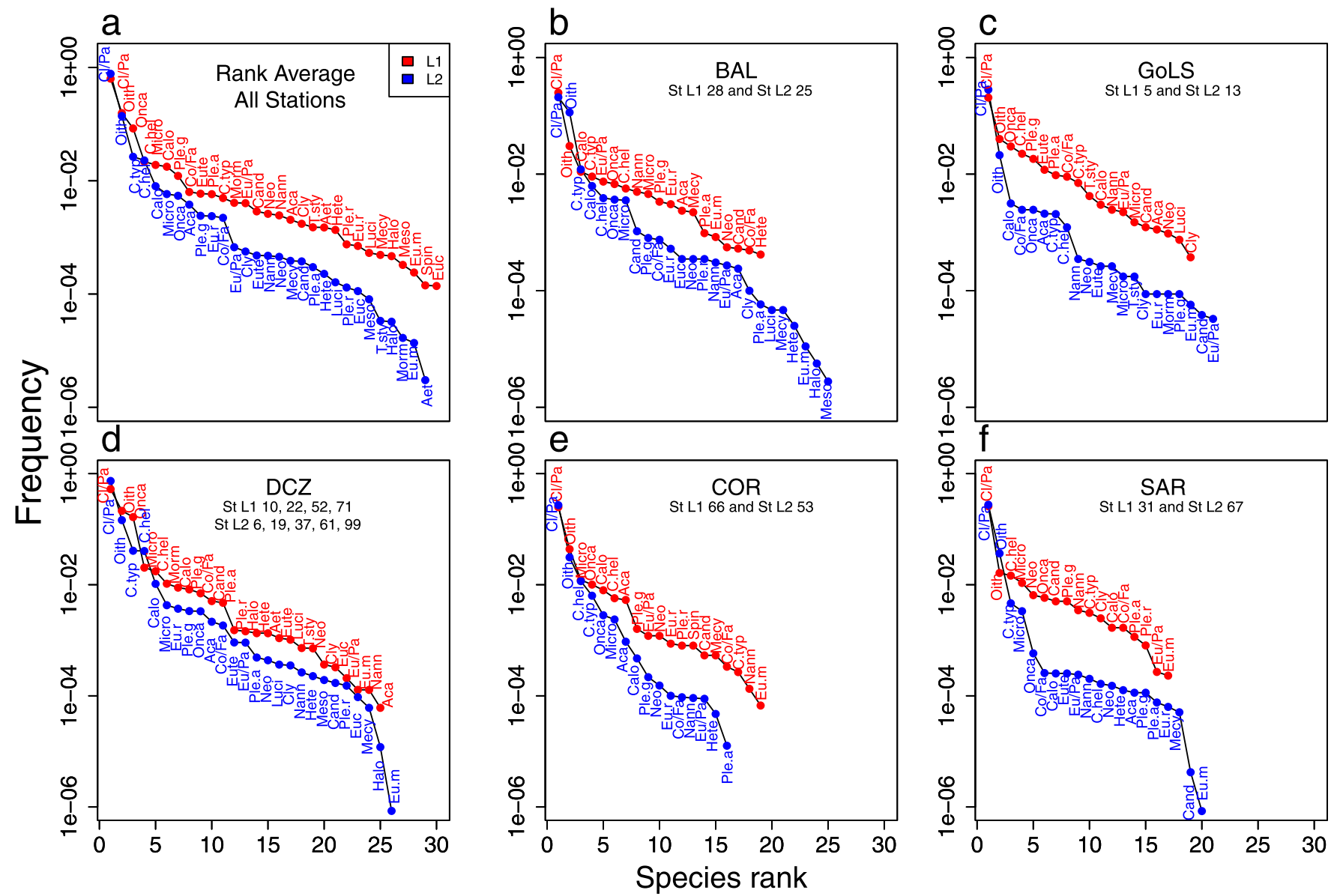

Figure 8. Rank frequency diagrams of copepod species for $L 1$ and $L 2$, for (a) the whole area, and (b-f) zones defined in Figure 1. The stations considered for each Zone are listed in the top of each plot. Species names are abbreviated according to Table 1.

The triplot shows environmental variables (blue arrows), species or size classes (in red), and stations (circles, color according to clusters shown in Figure 2).

\subsubsection{Copepod Community Composition and the Environment}

On L1, the first two CCA axes explained $39.71 \%$ of the variance in the species-environment relationships (Figure 11a). Aetideus spp. and Mormonilla spp. were associated with stations St 10, St 22, St 35, St 48, St 52 and St 71, all in the DCZ or near surrounding areas characterized by deep MLD. Euterpina acutifrons was associated with St 5 and St 16, northern coastal stations characterized by high chlorophyll- $a$ and oxygen. On L2, the first two CCA axes explained $45.53 \%$ of the variance (Figure $11 \mathrm{~b}$ ). Calanus helgolandicus was associated with stations St 6, St 19, St 30, St 37, St 61 and St 99, all of which were in the DCZ or surrounding areas and grouped in Cluster 1, characterized by high chlorophyll- $a$ and salinity, and low temperature values. Microsetella spp. was associated with St 67 on the Sardinian coast, a station characterized by high temperature.

\subsubsection{Copepod Size Structure and the Environment}

On L1, the first two CCA axes explain $50.45 \%$ of the variance in the size-environment relationships (Figure 11c). The first axis was positively correlated with size class. Small size classes $(0.3$ to $0.55 \mathrm{~mm})$ were associated with Cluster 1 stations (DCZ), characterized by high salinity, temperature and MLD. Large size classes ( 0.93 to $1.21 \mathrm{~mm}$ ) were associated with Clusters 2 and 3, characterized by high values of chlorophyll- $a$ and dissolved oxygen (peripheral stations). On L2, the first two CCA axes explained $58.99 \%$ of the variance (Figure $11 \mathrm{~d}$ ). The first axis was again correlated with size class. Small size classes $(0.3$, to $0.55 \mathrm{~mm}$ ) were associated with stations St 25, St 53 and St 95, which belonged to Cluster 2, and were positively correlated with temperature. Large size classes $(>1 \mathrm{~mm}$ ) were positively correlated with salinity and chlorophyll$a$ (Cluster 1). 


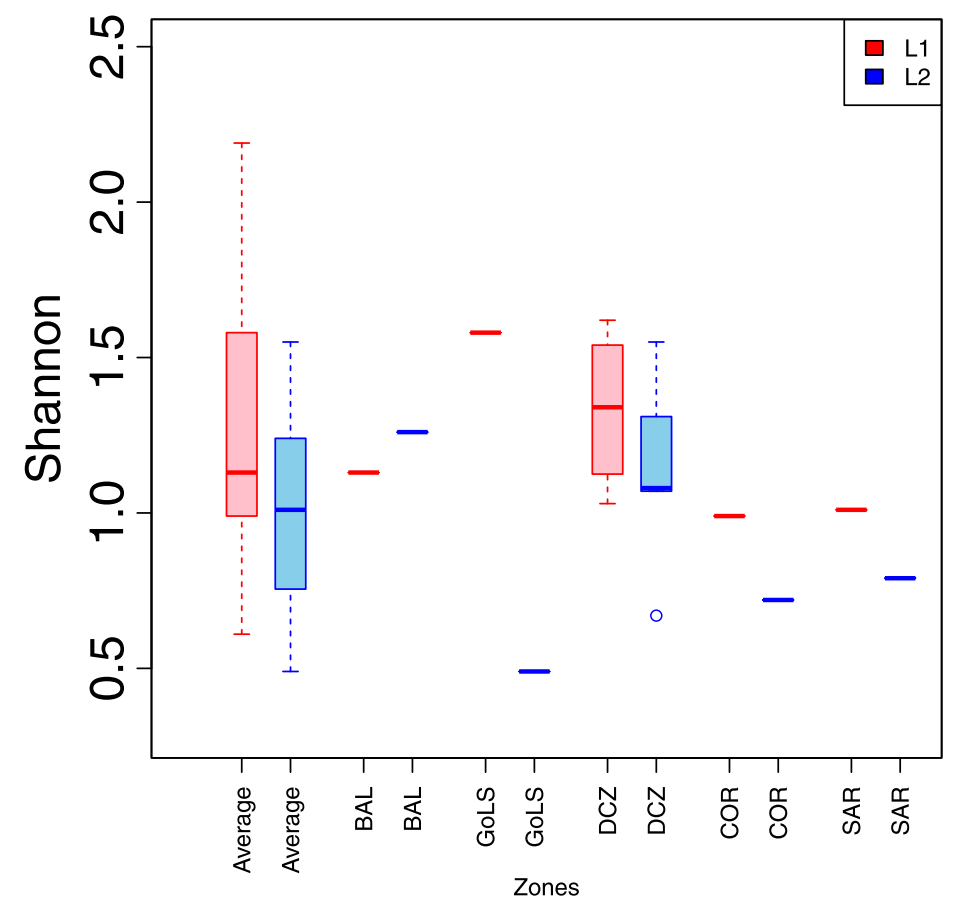

Figure 9. Shannon's diversity index for each cruise, for the whole survey area, and for each zone defined in Figure 1.

\subsection{Estimated Zooplankton Carbon Demand and Grazing Pressure}

ZCD values were estimated using a combination of copepod biomass $\left(B_{\text {zoo }}\right)$, food biomass $\left(C_{a}\right.$ assumed as phytoplankton here), and temperature (Figure 12). From winter to spring, phytoplankton stock strongly increases in the DCZ, while it decreased in peripheral zones (Figure 12a). Calculated ZCD values were $0.5 \pm 0.5$ and $5.85 \pm$ $6.2 \mathrm{mg} \mathrm{C} \mathrm{m}^{-3} \mathrm{~d}^{-1}$, for the L1 and $\mathrm{L} 2$ periods respectively, i.e., 1 order of magnitude higher in spring than in winter. In winter (L1) the DCZ, COR and SAR Zones displayed the lowest ZCD values (see Figure 12b), down to $0.057 \mathrm{mg} \mathrm{C} \mathrm{m}^{-3} \mathrm{~d}^{-1}$ (L1-St 22), while in the GoLS and BAL Zones ZCD was $\sim 10$ times higher. In all regions the ZCD strongly increases from winter to spring. The largest difference in spring were found in the DCZ, GoLS and SAR Zones, with maximum values in the central part of the DCZ (L2-St 61, $21.64 \mathrm{mg} \mathrm{C} \mathrm{m}^{-3} \mathrm{~d}^{-1}$ ). As a consequence, estimated grazing pressure by copepods on phytoplankton increased significantly from L1 (1.3 to 23.47 , mean $=7.5 \% \mathrm{~d}^{-1}$ ) to $\mathrm{L} 2$ (13.2 to 114.5 , mean $\left.=45.7 \% \mathrm{~d}^{-1}\right)$ (Figure $12 \mathrm{c}$ ).

\section{Discussion}

\subsection{Changes in Spatial Pattern of Environmental Variables During Winter-Spring Transition}

The winter 2012-2013 was particularly cold and windy inducing a strong deep convection in the central basin [Houpert et al., 2016]. As a consequence, the DCZ had a particularly deep MLD, low chlorophyll- $a$ levels, but high nutrient concentrations in the surface layer during the winter (K. Leblanc et al., unpublished data, 2016). In the spring the entire region became stratified (MLD $<100 \mathrm{~m}$ ). However, the DCZ maintained distinctly cooler and more saline water, while the high nutrients stimulated high phytoplankton growth and elevated chlorophyll-a values [Severin et al., 2014], providing favorable conditions to zooplankton grazers. This bottom up driven system of deep mixing and nutrient input in winter, followed by high zooplankton standing stock in spring, appears typical of the NWMS, based on the Balearic time series [Fernández de Puelles et al., 2007]. However, our results provide the first large scale spatial analysis of these patterns.

\subsection{Changes in Zooplankton Standing Stock During the Winter-Spring Transition}

The zooplankton sampling during DEWEX covered all the major circulation features of the NWMS region: the DCZ, the more stratified peripheral area, the LPCC, and the Balearic front.

As such, our results represent a regional mapping of zooplankton stocks during the winter spring transition period, the latter period when zooplankton standing stocks are generally highest in the NWMS [Saiz et al., 2014]. On average, zooplankton abundance values determined from net samples during the DEWEX spring cruise were higher than those found for the same circulation features in previous studies in the NWMS, DEWEX abundance was 1.8 times higher for the Ligurian Sea [Pinca and Dallot, 1995; Andersen et al., 2001], 2 times higher for the Balearic Sea [Fernández de Puelles et al., 2003], and 3 times higher for the Gulf of Lion [Gaudy and Champalbert, 1998]. 

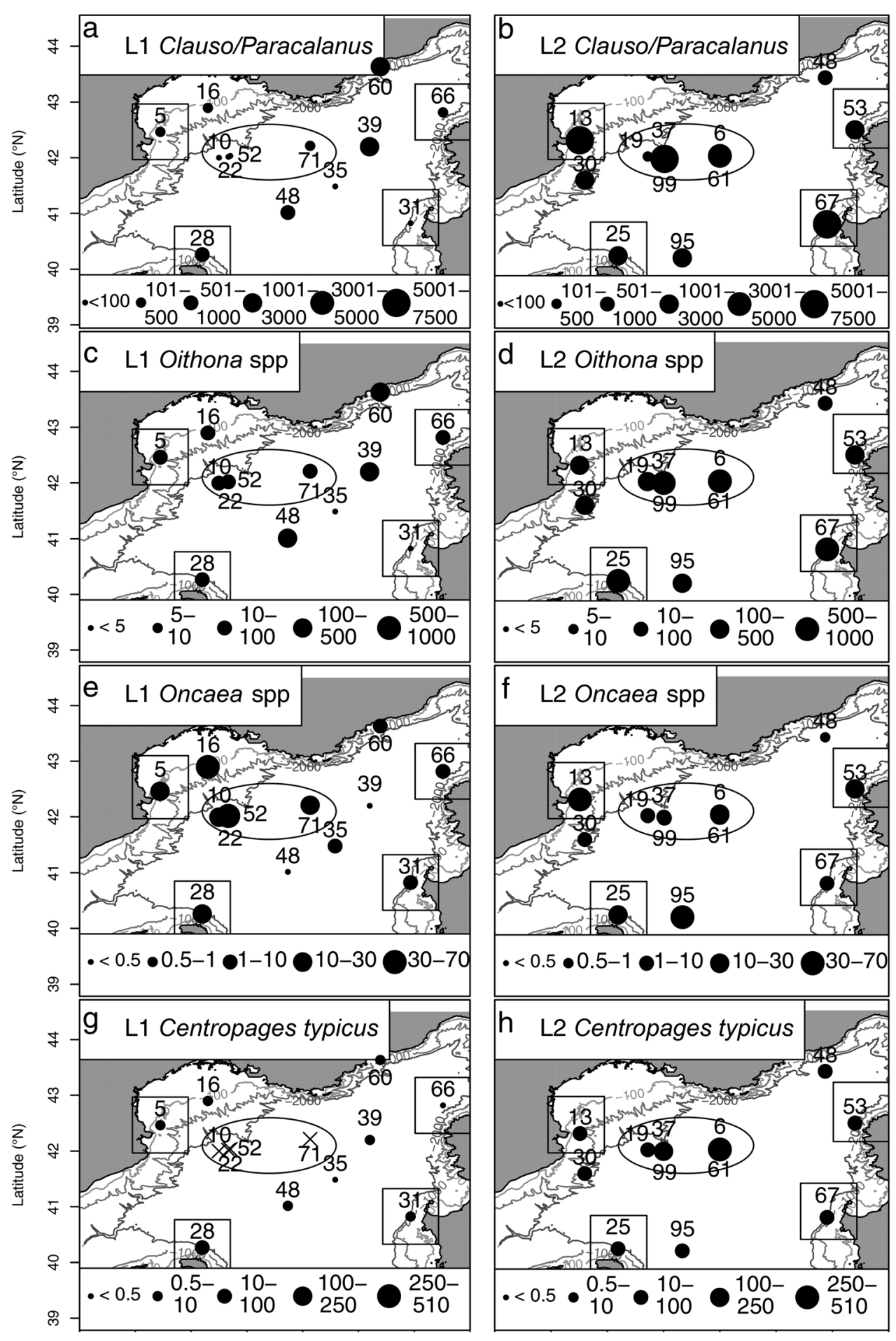

Figure 10. Abundance (ind. $\mathrm{m}^{-3}$ ) distribution of key copepod taxa during (a, c, e, g, i, k, m) L1 and (b, d, f, h, j, l, n.) L2.

We attribute the elevated abundance levels recorded during DEWEX L2 primarily to two factors. First, a smaller than previously used mesh size $(120 \mu \mathrm{m})$ likely results in a more efficient sampling of highly abundant small zooplankton species and larval stages [Calbet et al., 2001], which were particularly abundant in spring. Second, a particularly strong convection occurred during the preceding months, a process favoring 


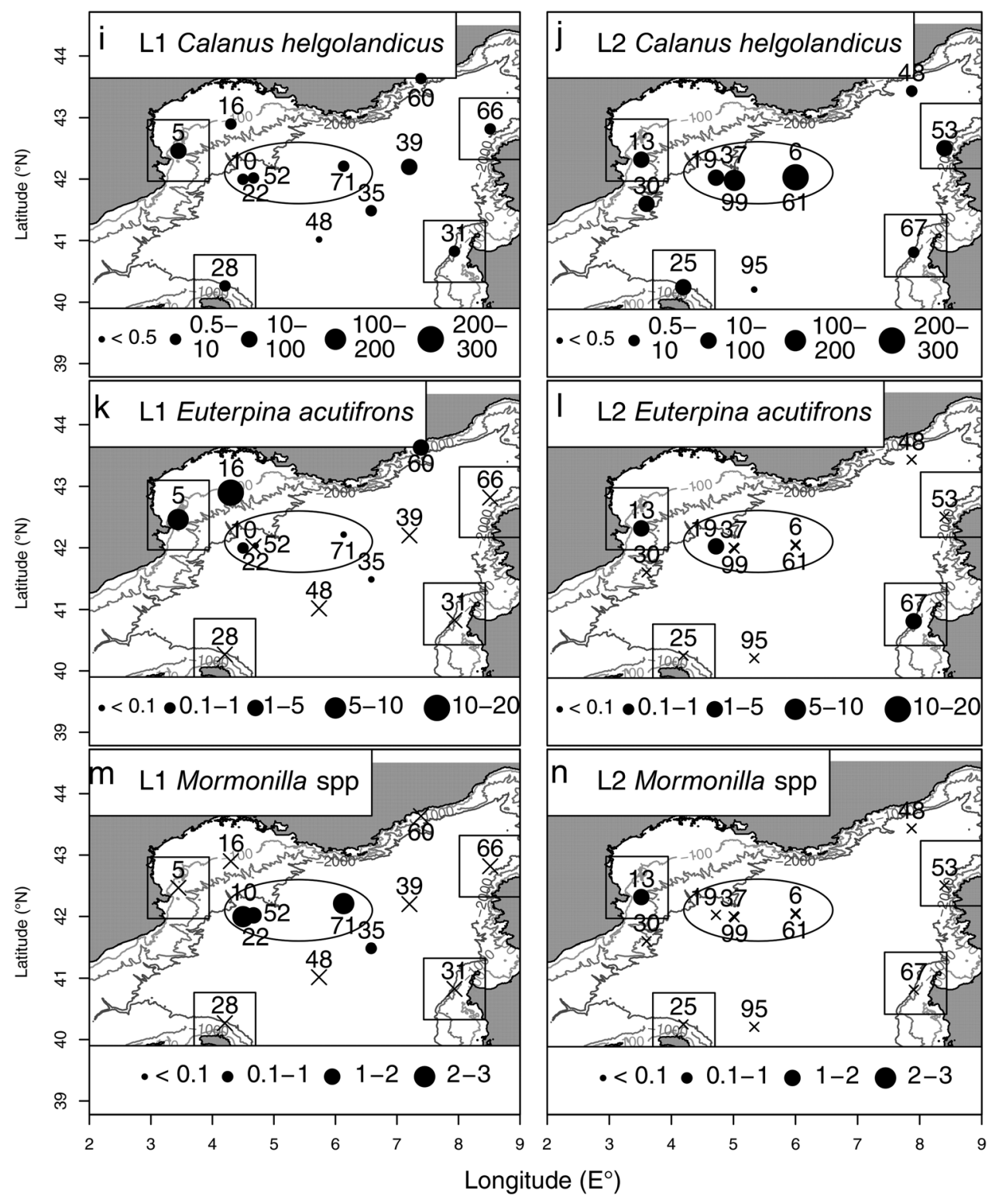

Figure 10. (Continued)

high zooplankton production in spring as observed in the Balearic time series [Fernández de Puelles et al., 2007].

The zooplankton biomass values recorded during DEWEX showed a large seasonal increase. This seasonal increase was particularly strong in the $D C Z$, reflecting the enhanced nutrient inputs into this zone which, coupled with spring stratification, stimulated primary productivity and subsequently secondary production. Stratification may also have contributed to high zooplankton abundance and biomass through concentrating zooplankton at the surface and/or limiting the vertical mixing typical of the winter when the zooplankton would have been more deeply mixed [Farstey et al., 2002].

Nival et al. [1975], working in the convection zone, reported a similar seasonal increase in biomass, from 0.4 to $53 \mathrm{mg} \mathrm{DW} \mathrm{m}^{-3}$ in the late winter to $10-210 \mathrm{mg} \mathrm{DW} \mathrm{m}^{-3}$ in the early spring. This seasonal pattern has been observed in other studied regions of the NWMS [Gaudy, 1985; Gaudy et al., 2003; Saiz et al., 2014], though not reaching the high levels observed in the DCZ (see the data compilation in Alcaraz et al. [2007]). For example, a seasonal increase from $12 \mathrm{mg} \mathrm{DW} \mathrm{m}^{-3}$ in February to $30 \mathrm{mg} \mathrm{DW} \mathrm{m}^{-3}$ in April was observed in the Ligurian Sea [Berline et al., 2011]. 

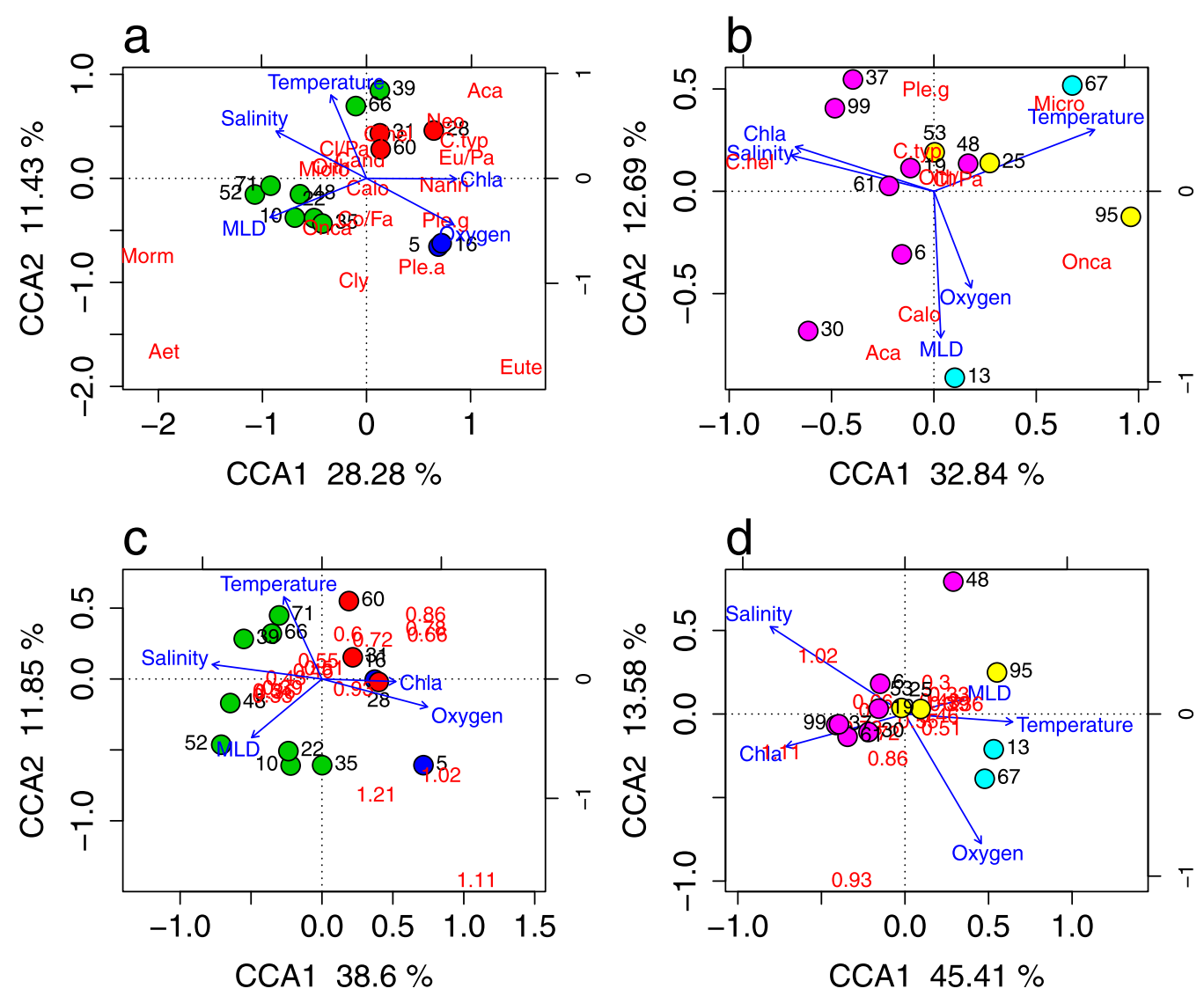

Figure 11. Canonical Correspondence Analysis triplot of abundance based copepod community structure and environmental variables for (a) L1 and (b) L2. Copepod size structure (size classes in red) and environmental variables (c) L1, (d) L2. Species names (red) according to abbreviations in Table 1. Circles according to color of cluster classification of the stations (see Figure 2).

The comparison of UVP counts and abundance of large copepods ( $>600 \mu \mathrm{m})$ in the nets delivered a good correlation although it should be carefully interpreted due to the low numbers of net tows and the undersampling of large copepods by both the UVP and the $120 \mu \mathrm{m}$ mesh size net. UVP counts were significantly positively correlated with depth-average chlorophyll- $a\left(r_{s}=0.60\right)$ and negatively correlated with depthaverage temperature $\left(r_{\mathrm{s}}=-0.69\right)$, with most high UVP counts located in the NW portion of the area. There
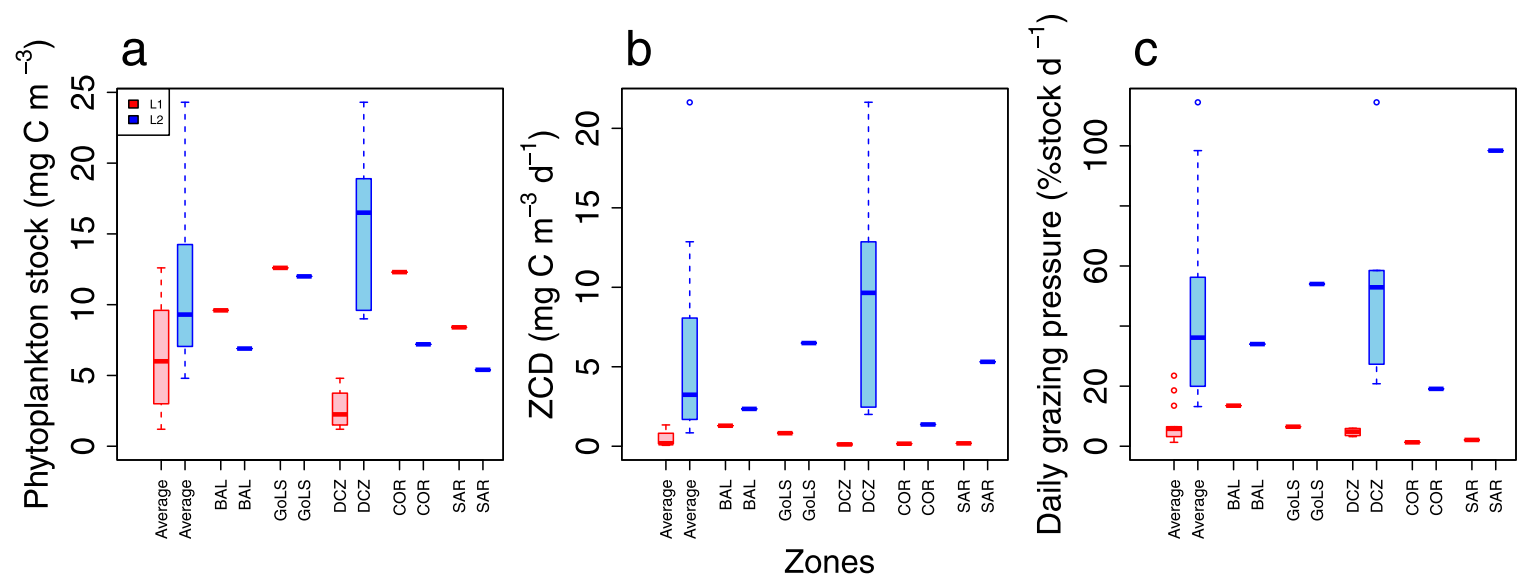

Figure 12. Changes in (a) phytoplankton stock, (b) zooplankton carbon demand and (c) daily grazing pressure (expressed as percentage of the phytoplankton stock grazed) in the five Zones defined in Figure 1. 
was a significant scatter in these relationships indicating the potential impact of patchiness and/or undersampling by the UVP. Although mesoscale features are well identified in the central NWMS [Escudier et al., 2016], and do impact zooplankton [Pinca and Dallot, 1997; Alcaraz et al., 2007; Carlotti et al., 2014], only one eddy was identified during L2 along the Balearic Front but this feature was not sampled.

\subsection{Peculiarity of the Deep Convection Zone (DCZ)}

The zooplankton dynamics in the DCZ differed from the periphery and coastal zones. The DCZ had the lowest zooplankton biomass in winter and the highest in spring. This strong zooplankton biomass increase was likely a response to first the concentration of the winter population in the upper layer due to stratification, and second to the growth of this population in response to the increased phytoplankton stock. Consequently in spring (L2) the zooplankton NBSS slopes remained flat reflecting an increase of both small and large individuals.

In the areas surrounding the DCZ, zooplankton biomass did not change substantially from winter to spring, remaining at comparatively low values, while abundance values increased, and consequently NBSS slopes were steeper than those observed in the DCZ. These steeper NBSS slopes may have resulted from the dominance of midsize copepod species (see Figure 8) with relatively short generation times [Zhou, 2006] from late winter to spring.

Accordingly, ZCD was highest in the DCZ. However, grazing pressure in the DCZ was not very high due to the large available phytoplankton biomass in this region. This feature of the DCZ was also seen in the satellite derived time series of surface chlorophyll- $a$ : the bloom started later compared to the periphery, but with a higher peak [Mayot et al., 2016]. This difference in timing and nutrient input between the DCZ and surrounding area resulted in a different development of the zooplankton community.

\subsection{Effect of the Environment on Zooplankton Community Structure}

For the zooplankton community as a whole, we found a similar composition for both periods, comprising $\sim 95 \%$ copepods, which is in the higher range of observed copepod dominance values in the Gulf of Lion (45-95\%) [Champalbert, 1996], the Ligurian Sea (87-98\%) [Andersen et al., 2001], the Catalan Sea (> 80\%) [Calbet et al., 1996], and in the vicinity the Balearic Islands (78\%) [Fernández de Puelles et al., 2004a]. See also the general overview by Saiz et al. [2014]. The high dominance of copepods in our study was likely in part due to the sampling of small forms by the $120 \mu \mathrm{m}$ mesh size [Calbet et al., 2001], but overall indicated the dominance of small copepods ( $\sim 1 \mathrm{~mm}$ in total length) as the major feature of the structure of mesozooplankton communities at the basin level in the NWMS [Siokou-Frangou et al., 2010]. Moreover, the open ocean is usually more dominated by copepods than coastal areas, where neritic forms such as cladocerans and meroplankton are generally also very abundant [Ramfos et al., 2006]. The dominant copepod taxa during DEWEX were typical Mediterranean off-shore species of large size (C. helgolandicus, $>2 \mathrm{~mm}$ ), medium size (Clausocalanus/Paracalanus spp, Centropages typicus, Calocalanus, Acartia spp, $2-1 \mathrm{~mm}$ ) and small size (Microsetella, Oithona spp. and Oncaea spp, $<1 \mathrm{~mm}$ ). This taxonomic composition found here differed slightly from coastal observations reviewed by Saiz et al. [2014], primarily with respect to the large and medium size taxa. Important non-copepod species observed during DEWEX were Appendicularians, also observed by Fernandez de Puelles et al. [2007], and Euphausiid larvae in spring, corresponding with their reproduction period in the NWMS [Cuzin-Roudy et al., 2004].

The rank-frequency diagrams obtained during DEWEX for the two legs (Figure 8) were typical of the initial and early phases of zooplankton seasonal successions, with a few very dominant taxa, a large component of taxa present in low densities, and a few rare species [Frontier, 1976, 1985]. The two first taxa (Clausocalanus/Paracalanus spp. and Oithona spp.) dominated in both legs with the same ranks. However, the strong increase of the small herbivorous copepods of the group Clausocalanus/Paracalanus spp., and to a lesser extent of Oithona spp., induced lower frequencies for the lower ranked species in L2 compared to L1. Among the lower ranked species, Centropages typicus showed the highest increase, from the ninth to the third rank from L1 to L2. Conversely, Oncaea spp. decreased from third to seventh rank between the two periods. Centropages typicus and Calanus helgolandicus are known to grow mainly on the phytoplankton bloom in late winter and early spring in the North Western Mediterranean Sea, at water temperatures below and around $15^{\circ} \mathrm{C}$ [Halsband-Lenk et al., 2001; Gaudy et al., 2003; Bonnet et al., 2005; Carlotti et al., 2014], and 
they clearly benefited from the primary production in the DCZ during DEWEX (Figure 10). The lower ranked copepod species were mostly herbivorous (Calocalanus spp., Microsetella spp., and Acartia spp.), followed by omnivorous (Mesocalanus tenuicorni and Oncaea spp.) and carnivorous (Euchaeta/Paraeuchaeta spp., Corycaeus/Farranula spp., and Mormonilla spp.)

Through CCA a clear association of some species to certain environmental variables was observed. In winter (L1), Mormonilla spp. and Aetideus spp. were associated with stations with a deep MLD, which is characteristic of the convection condition. These two species are generally found below the surface layers, below 250 m [Scotto Di Carlo et al., 1984; Böttger-Schnack, 1997]. The presence of these two genera only during the convection period suggested that deep convection transported them to the surface layers during the winter. Euterpina acutifrons had a clear association with the coastal stations (Cluster 3 in L1) with high oxygen, chlorophyll- $a$, and low temperature. This species is very common in neritic and coastal waters in the NWMS where it reproduces throughout the year [Viñas and Gaudy, 1996; Nowaczyk et al., 2011]. Due to its ability to feed on detritus [Goswami, 1975], E. acutifrons is often associated with estuarine [Díaz et al., 2003] or coastal [Viñas and Gaudy, 1996] particle-rich waters with high detritus load. This may explain its association with coastal stations (L1-St5 and St16) under the influence of the Rhone River.

In spring (L2), Microsetella spp. and Oncaea spp. were associated with high temperature areas whereas Calanus helgolandicus was associated with high salinity and high chlorophyll-a, indicative of the DCZ. Microsetella spp. and Oncaea spp. are known to be opportunistic feeders living in the surface layers, with the population growth following the temperature cycle [Turner, 2004; Uysal and Shmeleva, 2012]. On the contrary Calanus helgolandicus mainly inhabits the intermediate and deep layers of the NWMS, and ascends to epipelagic waters in late winter-spring [Bonnet et al., 2005], where it can be found in association with high phytoplankton concentrations [Boucher, 1984].

For each leg, the relationships between environmental variables and community composition were similar, as was the case with environmental variables and size structure, as evidenced by the CCA triplots. This may have been due to the strong environmental gradients, driving both size distribution and species composition. Size classes were correlated with food availability (chlorophyll-a), as found by Garcia-Comas et al. [2016] and San Martin et al. [2006], with large size classes being associated with food-rich waters. These large size classes were found in the periphery of the DCZ in winter and within the DCZ in spring. Small size classes were associated with high temperatures, especially in spring. As temperature and food were negatively correlated, the small sizes may have been due to the bottom up effect of low food availability. Small sizes may also have been a result of a direct effect of temperature on zooplankton, as temperature affects metabolic rates and development times [Richardson, 2008], resulting in decreasing individual body size in ectotherms with increasing temperature [Atkinson, 1994].

\subsection{Zooplankton Grazing Pressure on Phytoplankton}

The spring phytoplankton community in the entire DEWEX survey was dominated by nanophytoplankton (size range 2-10 $\mu \mathrm{m}$, estimated from flow cytometry, G. Gregory (unpublished data, 2016); and microscopy K. Leblanc (unpublished data, 2016)). This small size phytoplankton constitutes readily available food for many zooplankters, including the majority of filter-feeding copepods [Mullin, 1980]. Estimated copepod grazing pressure on phytoplankton increased significantly from L1 to L2. In the DCZ, the increase in ZCD was correlated with a large increase in both zooplankton and phytoplankton biomass, indicating that this region was bottom up controlled. Conversely, outside of the DCZ the increased ZCD was only due to the increase of zooplankton biomass, as phytoplankton biomass was low and even decreased, suggesting that top-down control during the bloom period (spring) may have been significant in these regions. Our grazing estimates are similar to those of previous studies, suggesting that a strong zooplankton top-down control on phytoplankton may be typical in the western Mediterranean Sea in both coastal [Gaudy et al., 2003; Vandromme et al., 2011] and open ocean sites outside of the DCZ. This estimated grazing impact was high in comparison with the North Atlantic, where Dam et al. [1993] found mesozooplankton grazing impact during the spring bloom to average $24.5 \mathrm{mg} \mathrm{C} \mathrm{m}^{-2} \mathrm{~d}^{-1}$, equivalent to the removal of $2.7 \% \mathrm{~d}^{-1}$ of the daily primary production. The large number of aggregates and fecal pellets $(>250 \mu \mathrm{m})$ observed below $100 \mathrm{~m}$ during spring on UVP images (data not shown) further support strong grazing activity and efficient clearance of phytoplankton by grazers, transferred to the large particle pool and contributing to export during DEWEX. 


\section{Conclusions}

We describe the spatial and temporal variability of the zooplankton community composition and functioning during two synoptic surveys in winter and spring 2013 in the NWMS. During the winter the central part of the survey area was a zone of deep convection, bringing cold, more saline, and nutrient rich water to the surface. The presence of deep water in the DCZ was further evidenced by the occurrence of deep water copepod species in the epipelagic zone. During the winter cruise, phytoplankton and zooplankton biomasses were low in the DCZ and relatively higher at the stations peripheral to the DCZ where stratification had been initiated. During the spring cruise, the observed increase of zooplankton biomass in the areas peripheral to the DCZ induced a strong depletion of phytoplankton through top-down control by zooplankton in these stratified conditions. In the DCZ, the spring zooplankton biomass was one order of magnitude higher than the winter survey. However, the spring chlorophyll values in DCZ remained high despite the high zooplankton biomass and carbon demand, indicating a sustained bottom-up control. This suggested that at the time of the spring survey the bloom in the periphery was decaying while in the DCZ the bloom was still active. On average for the whole area, the potential grazing impact was estimated to increase by one order of magnitude between winter and spring. The community taxonomic composition was comparable for both periods, with a high dominance of copepods, but with differences between the DCZ and peripheral regions. In spring, the DCZ was dominated by larger zooplankton individuals, particularly a high dominance of herbivorous copepod species such as Centropages typicus and Calanus helgolandicus associated with phytoplankton rich waters, and it likely represented a region of both efficient and enhanced energy transfer to higher trophic levels and high export.

\section{Acknowledgments}

We thank the project the coordinators and chief scientists on board, P. Conan and $\mathrm{P}$. Testor, for inviting us to take part in the MERMEX-DEWEX project and for supplying data. The authors thank the captain and crew of the R/V. Le Suroît, for their support on board. We also thank M. Picheral for advices on ECOTAXA software and UVP data processing, and K. Leblanc, G Gregori and $F$. VanWambeke for discussions on their environmental and phytoplankton data from DEWEX cruises. R. Leroux for collaboration with UVP data. We thank the two reviewers for their constructive remarks and suggestions, which significantly contributed to improving the quality of the publication. K. Donoso was supported by BecasChile Ph. D. scholarship (CONICYTGovernment of Chile). We acknowledge sponsorship from the MISTRALS-MERMEX project. All data used are available through http:// mistrals.sedoo.fr/MERMeX/

\section{References}

Alcaraz, M. (1985), Vertical distribution of zooplankton biomass during summer stratification in the Western Mediterranean, in Proceedings of the 19th European Marine Biology Symposium, edited by P. E. Gibbs, pp. 135-143, Plymouth, Devon, Cambridge University Press, Cambridge.

Alcaraz, M., A. Calbet, M. Estrada, C. Marrasé, E. Saiz, and I. Trepat (2007), Physical control of zooplankton communities in the Catalan Sea, Prog. Oceanogr., 74(2-3), 294-312, doi:10.1016/j.pocean.2007.04.003.

Andersen, V., A. Gubanova, P. Nival, and T. Ruellet (2001), Zooplankton community during the transition from spring bloom to oligotrophy in the open NW Mediterranean and effects of wind events: 2. Vertical distributions and migrations, J. Plankton Res., 23(3), $243-261$.

Atkinson, D. (1994), Temperature and organism size-A biological law for ectotherms?, in Advances in Ecological Research, vol. 25, edited by M. Begon and A. H. Fitter, pp. 1-58, Academic Press, Elsevier, Cambridge, Mass.

Berline, L., L. Stemmann, M. Vichi, F. Lombard, and G. Gorsky (2011), Impact of appendicularians on detritus and export fluxes: A model approach at DyFAMed site, J. Plankton Res., 33(6), 855-872, doi:10.1093/plankt/fbq163.

Bonnet, D., et al. (2005), An overview of Calanus helgolandicus ecology in European waters, Prog. Oceanogr., 65(1), 1-53, doi:10.1016/ j.pocean.2005.02.002

Böttger-Schnack, R. (1997), Vertical structure of small metazoan plankton, especially non-calanoid copepods. II. Deep Eastern Mediterranean (Levantine Sea), Oceanol. Acta, 20(2), 399-419.

Boucher, J. (1984), Localization of zooplankton populations in the Ligurian marine front: Role of ontogenic migration, Deep Sea Res., Part A, 31(5), 469-484, doi:10.1016/0198-0149(84)90097-9.

Calbet, A., M. Alcaraz, E. Saiz, M. Estrada, and I. Trepat (1996), Planktonic herbivorous food webs in the Catalan Sea (NW Mediterranean): Temporal variability and comparison of indices of phyto-zooplankton coupling based on state variables and rate processes, J. Plankton Res., 18(12), 2329-2347.

Calbet, A., S. Garrido, E. Saiz, M. Alcaraz, and C. M. Duarte (2001), Annual zooplankton succession in coastal NW Mediterranean Waters: The importance of the smaller size fractions, J. Plankton Res., 23(3), 319-331, doi:10.1093/plankt/23.3.319.

Calinski, T., and J. Harabasz (1974), A dendrite method for cluster analysis, Commun. Stat. Theory Methods, 3(1), 1-27, doi:10.1080/ 03610927408827101.

Carlotti, F., L. Eisenhauer, R. Campbell, and F. Diaz (2014), Modeling the spatial and temporal population dynamics of the copepod Centropages typicus in the northwestern Mediterranean Sea during the year 2001 using a 3D ecosystem model, J. Mar. Syst., 135, 97-116, doi: 10.1016/j.jmarsys.2013.11.007.

Champalbert, G. (1996), Characteristics of zooplankton standing stock and communities in the Western Mediterranean Sea: Relations to hydrology, Sci. Mar., 60, 97-113.

Clarke, K. R., and R. M. Warwick (1994), An approach to statistical analysis and interpretation, Change Mar. Communities, 2, 8-1-8-12.

Cuzin-Roudy, J., G. Tarling, and J. Stromberg (2004), Life cycle strategies of Northern krill (Meganyctiphanes norvegica) for regulating growth, moult, and reproductive activity in various environments: The case of fjordic populations, ICES J. Mar. Sci., 61(4), 721-737, doi: 10.1016/j.icesjms.2004.03.008.

Dam, H. G., C. A. Miller, and S. H. Jonasdottir (1993), The trophic role of mesozooplankton at 47 N, 20 W during the North Atlantic Bloom Experiment, Deep Sea Res., Part II, 40(1-2), 197-212.

De Boyer Montégut, C., G. Madec, A. S. Fischer, A. Lazar, and D. ludicone (2004), Mixed layer depth over the global ocean: An examination of profile data and a profile-based climatology, J. Geophys. Res., 109, C12003, doi:10.1029/2004JC002378.

Delgado, M., M. Latasa, and M. Estrada (1992), Variability in the size-fractionated distribution of the phytoplankton across the Catalan front of the north-west Mediterranean, J. Plankton Res., 14(5), 753-771.

Díaz, E., U. Cotano, and F. Villate (2003), Reproductive response of Euterpina acutifrons in two estuaries of the Basque Country (Bay of Biscay) with contrasting nutritional environment, J. Exp. Mar. Biol. Ecol., 292(2), 213-230, doi:10.1016/S0022-0981(03)00179-5. 
D'Ortenzio, F., and M. Ribera d'Alcalà (2009), On the trophic regimes of the Mediterranean Sea: A satellite analysis, Biogeosciences, 6(2), $139-148$.

Escudier, R., L. Renault, A. Pascual, P. Brasseur, D. Chelton, and J. Beuvier (2016), Eddy properties in the western Mediterranean Sea from satellite altimetry and a numerical simulation, J. Geophys. Res. Oceans, 121, 3990-4006, doi:10.1002/2015JC011371.

Estrada, M. (1996), Primary production in the northwestern Mediterranean, Sci. Mar., 60(2), 55-64.

Farstey, V., B. Lazar, and A. Genin (2002), Expansion and homogeneity of the vertical distribution of zooplankton in a very deep mixed layer, Mar. Ecol. Prog. Ser., 238, 91-100.

Fernández de Puelles, M., J.-M. Pinot, and J. Valencia (2003), Seasonal and interannual variability of zooplankton community in waters off Mallorca island (Balearic Sea, Western Mediterranean): 1994-1999, Oceanol. Acta, 26(5-6), 673-686, doi:10.1016/j.oceact.2003.07.001.

Fernández de Puelles, M. L., J. Valencia, J. Jansa, and A. Morillas (2004a), Hydrographical characteristics and zooplankton distribution in the Mallorca channel (Western Mediterranean): Spring 2001, ICES J. Mar. Sci., 61(4), 654-666, doi:10.1016/j.icesjms.2004.03.031.

Fernández de Puelles, M. L., J. Valencia, and L. Vicente (2004b), Zooplankton variability and climatic anomalies from 1994 to 2001 in the Balearic Sea (Western Mediterranean), ICES J. Mar. Sci., 61(4), 492-500, doi:10.1016/j.icesjms.2004.03.026.

Fernández de Puelles, M. L., F. Alemany, and J. Jansá (2007), Zooplankton time-series in the Balearic Sea (Western Mediterranean): Variability during the decade 1994-2003, Prog. Oceanogr., 74(2), 329-354.

Frontier, S. (1976), Étude de la décroissance des valeurs propres dans une analyse en composantes principales: Comparaison avec le modèle du bâton brisé, J. Exp. Mar. Biol. Ecol., 25(1), 67-75, doi:10.1016/0022-0981(76)90076-9.

Frontier, S. (1985), Diversity and structure in aquatic ecosystems, Oceanogr. Mar. Biol., 23, 253-312.

Furnestin, M.-L. (1960), Zooplancton du Golfe du Lion et de la côte orientale de Corse, Rev. Trav. Inst. Pêch. Marit., 24(2), 153-252.

García-Comas, C., L. Stemmann, F. Ibanez, L. Berline, M. G. Mazzocchi, S. Gasparini, M. Picheral, and G. Gorsky (2011), Zooplankton longterm changes in the NW Mediterranean Sea: Decadal periodicity forced by winter hydrographic conditions related to large-scale atmospheric changes?, J. Mar. Syst., 87(3-4), 216-226, doi:10.1016/j.jmarsys.2011.04.003.

García-Comas, C., Y.-C. Lee, C.-Y. Chang, G.-C. Gong, and C.-H. Hsieh (2016), Comparison of copepod species-based and individual-sizebased community structuring, J. Plankton Res., 38(4), 1006-1020, doi:10.1093/plankt/fbw039.

Gaudy, R. (1985), Features and peculiarities of zooplankton communities from the western Mediterranean, in Mediterranean marine ecosystems, pp. 279-301, Springer, Boston, Mass.

Gaudy, R., and G. Champalbert (1998), Space and time variations in zooplankton distribution south of Marseilles, Oceanol. Acta, 21(6), 793-802.

Gaudy, R., F. Youssara, F. Diaz, and P. Raimbault (2003), Biomass, metabolism and nutrition of zooplankton in the Gulf of Lions (NW Mediterranean), Oceanol. Acta, 26(4), 357-372, doi:10.1016/S0399-1784(03)00016-1.

Gorsky, G., M. D. Ohman, M. Picheral, S. Gasparini, L. Stemmann, J.-B. Romagnan, A. Cawood, S. Pesant, C. Garcia-Comas, and F. Prejger (2010), Digital zooplankton image analysis using the ZooScan integrated system, J. Plankton Res., 32(3), 285-303, doi:10.1093/plankt/ fbp124.

Goswami, S. C. (1975), Larval stages of laboratory reared harpacticoid copepod Euterpina acutifrons (Dana), Mahasagar, 8(3-4), 123-132.

Halsband-Lenk, C., S. Nival, F. Carlotti, and H.-J. Hirche (2001), Seasonal cycles of egg production of two planktonic copepods, Centropages typicus and Temora stylifera, in the north-western Mediterranean Sea, J. Plankton Res., 23(6), 597-609.

Herman, A. W., and M. Harvey (2006), Application of normalized biomass size spectra to laser optical plankton counter net intercomparisons of zooplankton distributions, J. Geophys. Res., 111, C05S05, doi:10.1029/2005JC002948.

Houpert, L., et al. (2016), Observations of open-ocean deep convection in the Northwestern Mediterranean Sea: Seasonal and Interannual variability of mixing and Deep Water Masses for the 2007-2013 period, J. Geophys. Res. Oceans, 121, 8139-8171, doi:10.1002/ $2016 \mathrm{JC} 011857$.

Krupica, K. L., W. G. Sprules, and A. W. Herman (2012), The utility of body size indices derived from optical plankton counter data for the characterization of marine zooplankton assemblages, Cont. Shelf Res., 36, 29-40, doi:10.1016/j.csr.2012.01.008.

Lehette, P., and S. Hernández-León (2009), Zooplankton biomass estimation from digitized images: A comparison between subtropical and Antarctic organisms, Limnol Ocean. Methods, 7, 304-308.

Mayot, N., F. D’Ortenzio, V. Taillandier, L. Prieur, O. Pasqueron de Fommervault, H. Claustre, A. Bosse, P. Testor, and P. Conan (2016), Impacts of the deep convection on the phytoplankton blooms in temperate seas: A multiplatform approach over a complete annual cycle (2012-2013 DEWEX experiment), J. Geophys. Res. Oceans, in press.

McGehee, D. E., D. A. Demer, and J. D. Warren (2004), Zooplankton in the Ligurian Sea: Part I. Characterization of their dispersion, relative abundance and environment during summer 1999, J. Plankton Res., 26(12), 1409-1418, doi:10.1093/plankt/fbh132.

MEDOC GROUP (1970), Observation of formation of deep water in the Mediterranean Sea, 1969, Nature, 227(5262), 1037-1040, doi: 10.1038/2271037a0.

Millot, C. (1990), The gulf of Lions' hydrodynamics, Cont. Shelf Res., 10(9), 885-894.

Millot, C., and I. Taupier-Letage (2005), Circulation in the Mediterranean Sea, in The Mediterranean Sea, vol. 5K, edited by A. Saliot, pp. 2966, Springer, Berlin.

Molinero, J. C., F. Ibanez, P. Nival, E. Buecher, and S. Souissi (2005), North Atlantic climate and northwestern Mediterranean plankton variability, Limnol. Oceanogr. Methods, 50(4), 1213-1220.

Molinero, J. C., F. Ibanez, S. Souissi, E. Buecher, S. Dallot, and P. Nival (2008), Climate control on the long-term anomalous changes of zooplankton communities in the Northwestern Mediterranean, Global Change Biol., 14(1), 11-26, doi:10.1111/j.1365-2486.2007.01469.x.

Mullin, M. M. (1980), Interactions between marine zooplankton and suspended particles, in Particulates in Water, vol. 189, edited by M. C. Kavanaugh and J. O. Leckie, pp. 233-241, Am. Chem. Soc., Washington, D. C.

Nival, P., S. Nival, and A. Thiriot (1975), Influence des conditions hivernales sur les productions phyto-et zooplanctoniques en Méditerranée Nord-Occidentale. V. Biomasse et production zooplanctonique-relations phyto-zooplancton, Mar. Biol., 31(3), 249-270.

Nowaczyk, A., F. Carlotti, D. Thibault-Botha, and M. Pagano (2011), Distribution of epipelagic metazooplankton across the Mediterranean Sea during the summer BOUM cruise, Biogeosciences, 8(8), 2159-2177, doi:10.5194/bg-8-2159-2011.

Oksanen, J., F. G. Blanchet, R. Kindt, P. Legendre, P. R. Minchin, R. B. O'Hara, G. L. Simpson, P. Solymos, M. H. H. Stevens, and H. Wagner (2016), vegan: Community Ecology Package. R package version 2.4-1.

Picheral, M., L. Guidi, L. Stemmann, D. M. Karl, G. Iddaoud, and G. Gorsky (2010), The Underwater Vision Profiler 5: An advanced instrument for high spatial resolution studies of particle size spectra and zooplankton, Limnol. Oceanogr. Methods, 8, 462-473.

Picheral, M., S. Colin, and J.-O. Irisson (2015), EcoTaxa, a tool for the taxonomic classification of images. [Available at http://ecotaxa.obs-vlfr.fr.]

Pinca, S., and S. Dallot (1995), Meso-and macrozooplankton composition patterns related to hydrodynamic structures in the Ligurian Sea (Trophos-2 experiment, April-June 1986), Oceanogr. Lit. Rev., 5(43), 484. 
Pinca, S., and S. Dallot (1997), Zooplankton community structure in the Western Mediterranean sea related to mesoscale hydrodynamics, Hydrobiologia, 356(1-3), 127-142.

Ramfos, A., S. Isari, S. Somarakis, D. Georgopoulos, C. Koutsikopoulos, and N. Fragopoulu (2006), Mesozooplankton community structure in offshore and coastal waters of the lonian Sea (eastern Mediterranean) during mixed and stratified conditions, Mar. Biol., 150(1), 29-44, doi:10.1007/s00227-006-0326-0.

Rasband, W. S. (2005), ImageJ (Computer Program), U.S. Natl. Inst. Health, Bethesda, Md.

Razouls, C., F. De Bovée, J. Kouwenberg, and N. Desreumaux (2005), Diversity and geographic distribution of marine planktonic copepods. [Available at http://copepodes.obs-banyuls.fr/en.]

Richardson, A. J. (2008), In hot water: zooplankton and climate change, ICES J. Mar. Sci./J. Cons. Int. Explor. Mer., 65(3), 279-295.

Rose, M. (1933), Copépodes pélagiques, Faune de France.

Sabatés, A., J. M. Gili, and F. Pagès (1989), Relationship between zooplankton distribution, geographic characteristics and hydrographic patterns off the Catalan coast (Western Mediterranean), Mar. Biol., 103(2), 153-159.

Saiz, E., A. Sabatés, and J.-M. Gili (2014), The zooplankton, in The Mediterranean Sea, edited by S. Goffredo and Z. Dubinsky, pp. 183-211, Springer Netherlands, Dordrecht, Netherlands.

San Martin, E., R. P. Harris, and X. Irigoien (2006), Latitudinal variation in plankton size spectra in the Atlantic Ocean, Deep Sea Res. Part II, 53(14-16), 1560-1572, doi:10.1016/j.dsr2.2006.05.006.

Scotto Di Carlo, B., A. Ianora, E. Fresi, and J. Hure (1984), Vertical zonation patterns for Mediterranean copepods from the surface to $3000 \mathrm{~m}$ at a fixed station in the Tyrrhenian Sea, J. Plankton Res., 6(6), 1031-1056.

Severin, T., P. Conan, X. Durrieu de Madron, L. Houpert, M. J. Oliver, L. Oriol, J. Caparros, J. F. Ghiglione, and M. Pujo-Pay (2014), Impact of open-ocean convection on nutrients, phytoplankton biomass and activity, Deep Sea Res., Part I, 62-71, doi:10.1016/j.dsr.2014.07.015.

Siokou-Frangou, I., U. Christaki, M. G. Mazzocchi, M. Montresor, M. Ribera d'Alcalá, D. Vaqué, and A. Zingone (2010), Plankton in the open Mediterranean Sea: A review, Biogeosciences, 7(5), 1543-1586, doi:10.5194/bg-7-1543-2010.

Testor, P. et al. (2016), Observation of 2012-2013 deep convection events in the north-western Mediterranean Sea, J. Geophys. Res. Oceans, in press.

Tregouboff, G., and M. Rose (1957), Manual de Planctonologie Mediterranèenne, tomo II Centre Nacional de la Recherche Scientifique Paris, Tomo II Planche, 128-135.

Turner, J. T. (2004), The importance of small planktonic copepods and their roles in pelagic marine food webs, Zool. Stud., 43(2), $255-266$.

Uitz, J., H. Claustre, F. B. Griffiths, J. Ras, N. Garcia, and V. Sandroni (2009), A phytoplankton class-specific primary production model applied to the Kerguelen Islands region (Southern Ocean), Deep Sea Res., Part I, 56(4), 541-560, doi:10.1016/j.dsr.2008.11.006.

Uysal, Z., and A. A. Shmeleva (2012), Species composition, abundance and biomass of Copepoda in plankton of the northern Levantine Basin (eastern Mediterranean), Crustaceana, 85(8), 909-935, doi:10.1163/156854012X650179.

Vandromme, P., L. Stemmann, L. Berline, S. Gasparini, L. Mousseau, F. Prejger, O. Passafiume, J.-M. Guarini, and G. Gorsky (2011), Inter-annual fluctuations of zooplankton communities in the Bay of Villefranche-sur-mer from 1995 to 2005 (Northern Ligurian Sea, France), Biogeosciences, 8(11), 3143-3158, doi:10.5194/bg-8-3143-2011.

Vandromme, P., L. Stemmann, C. Garcia-Comas, L. Berline, X. Sun, and G. Gorsky (2012), Assessing biases in computing size spectra of automatically classified zooplankton from imaging systems: A case study with the ZooScan integrated system, Methods Oceanogr., $12-$, 3-21, doi:10.1016/j.mio.2012.06.001.

Viñas, M. D., and R. Gaudy (1996), Annual cycle of Euterpina acutifrons (Copepoda: Harpacticoida) in the Gulf of San Matías (Argentina) and in the Gulf of Marseilles (France), Sci. Mar., 60(2/3), 307-318.

Wiebe, P. H., S. Boyd, and J. L. Cox (1975), Relationships between zooplankton displacement volume, wet weight, dry weight, and carbon, Fish. Bull., 73(4), 777-786.

Zhou, M. (2006), What determines the slope of a plankton biomass spectrum?, J. Plankton Res., 28(5), 437-448, doi:10.1093/plankt/fbi119.

Zhou, M., F. Carlotti, and Y. Zhu (2010), A size-spectrum zooplankton closure model for ecosystem modelling, J. Plankton Res., 32(8), 11471165, doi:10.1093/plankt/fbq054. 